\title{
Nutritional, Sensory Evaluation and Biological Effect on diabetic rats of Cakes Enhanced with Pumpkin Fruit and Its Seeds
}

\author{
Manal M. E. M. Shehata * Hanan El-sayed ${ }^{* *}$ \\ *Food Sci. Dept. (Rural Home Economics - Food Science and Nutrition), Fac. \\ Agric., Zagazig Univ., Egypt \\ **Food Sci. Dept. (Rural Home Economics), Fac. Agric., Zagazig Univ., Egypt
}

\section{E-mail: manal.m.e.shehata@gmail.com}

\section{Abstract:}

The purpose of current study was to enhance the nutritional value of cakes by substituting wheat flour by pumpkin fruit and its seeds as a source of protein, phenolics and flavonoids. Cakes were made by substituting wheat flour with a constant percentage of fresh pumpkin fruit (10\% as dry weight) or replacement wheat flour with fresh pumpkin fruit using the same previous percentage and different levels of whole pumpkin seeds (10, 20, 30 and 40\%). The different kinds of cakes were subjected for nutritional and sensory evaluation. Effect of feeding with cakes enhanced with pumpkin fruit and its seeds on serum biochemical analysis and histological examination of pancreas for alloxan-induced diabetic male rats after three months treatment was also assessed. Results estimated that cakes containing both fresh pumpkin fruit and whole pumpkin seeds showed significantly increased $(\mathrm{P}<0.05)$ in protein, fiber, ash, phenolics and flavonoids as well as this increase was associated with the level of substituting by whole pumpkin seeds compared to control cakes. Sensory quality revealed that cakes containing fresh pumpkin fruit and $40 \%$ whole pumpkin seeds were the most acceptable comparing with control cakes. Data showed that glucose, triglycerides (TG), cholesterol (TC) and low-density lipoprotein (LDL) levels for diabetic rats which fed on cakes enhanced with fresh pumpkin fruit or cakes containing both fresh pumpkin fruit and different levels of whole pumpkin seeds significantly decreased $(\mathrm{P}<0.05)$ in comparison with diabetic rats, whereas, insulin and high-density lipoprotein levels were significantly higher $(\mathrm{P}<0.05)$ than diabetic rats. Findings revealed that a significant improve $(\mathrm{P}<0.05)$ in kidney and liver functions of diabetic rats treated with cakes enhanced with pumpkin (fruit or fruit and its seeds) compared to rats with diabetes. Histological analysis also clarified marked improvement in pancreatic tissues of diabetic rats treated with cakes enhanced 
with pumpkin (fruit and its seeds) comparing to diabetic rats and these findings are consistent with previous results mentioned above. The best improvement of different parameters was found in diabetic rats consumed cakes containing $40 \%$ whole pumpkin seeds and 10\% pumpkin fruit as compared with diabetic rats where parameters reached to nearly normal values. In addition, these cakes contain the highest values of protein, fiber, phenolics and flavonoids, and the lowest levels from fat and calories comparing to control cakes. Therefore, it can be concluded that cakes prepared from pumpkin (fruit or fruit and its seeds) which were produced by the lowest cost considered from functional foods where pumpkin and its seeds had beneficial effects on nutritional and biological parameters of cakes. According to results, these cakes could be beneficial in the prevention and treatment of diabetes. Also, pumpkin cakes might be useful for people suffering from hyperlipidemia, obesity and malnutrition. Thus, this will help to promote the use of pumpkin cakes and management problems related to nutrition in Egypt. So, this study recommends increasing the production of food products containing pumpkin (fruit or fruit and its seeds) and improving nutrition education of people about the importance of consuming food products made from pumpkin and its many benefits for preventing and treating diabetes as well as other diseases in different media.

Key words: Pumpkin, whole pumpkin seeds, diabetes mellitus, cakes, alloxan, nutritional value and sensory evaluation.

\section{Introduction:}

Diabetes is defined as a public health problem, popular, growing, danger, costly, and potentially preventable (Narayan et al., 2000). Diabetes is a metabolic disorder that causes hyperglycemia as a result of insulin deficient secretion or the inability of the human body to use the insulin hormone it produces efficiently (Gutch et al., 2014). Diabetics expose to infect with many complications that lead to the deterioration of their health condition, such as damage the heart, blood vessels, eyes, nerves and kidneys, in addition, raise the infection of stroke risk (Tripathi and Srivastava, 2006). Diabetes mellitus prevalence is a burden on health and resources of financial, which in turn, will affect individuals, families and nations. According to the statistics of 2019 (IDF, 2019), diabetics of the age group (20-79 years) around the world reach to 463 million, and that by 2045 diabetics number in the world will reach to 700 million, in addition, total health expenditures for diabetes reached USD760 billion. In 2019, deaths number due to diabetes reached to 4.2 million of adults (20-79 years) in the world. There are 55 million adults aged $20-79$ years have 
diabetes in the region of Middle East and North Africa, according to the Atlas in 2019, and will reach 108 million by 2045 and the increase will reach $96 \%$. Egypt among the 10 countries over the world most affected by diabetes, ranked ninth in worldwide. In Egypt diabetics number of adults (20-79 years) reached 8.9 million (IDF, 2019).

The consumption of food is directly related to preventing hunger and maintaining human health (Kulczyński et. al., 2020). Health is the main factor for consuming functional foods and the consumer knows that foods have a strong relationship to their health. Consumers today wish that foods not only prepared to satisfy hunger and provide essential nutrients to humans, but also, to prevent nutritional diseases and improve the state of health and mind (Betoret et al., 2011 and Goetzke et al., 2014).

Bakery products are consumed in all the world, especially cakes. Young and elderly prefer cakes consumption in rural and urban areas (Hosseini Ghaboos et al., 2018). Cakes are usually made from flour (often wheat flour), sweetener (usually sugar), fat and liquid. Cakes contain high calories from sugar and fat. (Clerk and Herbert, 2000 and Al-Tamim, 2014).

Food fortification is an improvement in the nutritional value of food by adding some nutrients such as proteins, vitamins and minerals using plant or animal sources. These fortified foods are appropriate for people suffering from malnutrition and some diseases (Abril et al., 2012). The worldwide attention attracted to the utilization of dietary plants and herbal preparations instead of medicine to prevent and treat diabetes mellitus (Hunt et al., 2000).

Pumpkin is extensively cultivated in tropical and subtropical countries (Bhaskarachary et al., 2008). Egypt considered as one of five main pumpkin producing countries in the worldwide (Khalifa et al., 2012). Pumpkin is one of plants which as a member of genus Cucurbita and family Cucurbitaceae. Pumpkin is known as fruit botanically though generally regarded as vegetable in consumer terms (Azizah et al., 2009). Pumpkin is rich in some nutrients and low fat and carbohydrates, making it a raw material easy to digest and low in calorie (Zdrojewicz et al., 2016). Pumpkin fruit is rich in nutrients such as phenolic compounds, vitamins, minerals and carotenoids (Cerniauskiene et al., 2014).

According to Milovanoic and Vucelic-Radovic, (2008), pumpkin seeds contain a high percentage of protein (25-37\%) and oil (37-45\%). In addition, pumpkin seeds are rich source in polyunsaturated fatty acids (Sabudak, 2007), 
phytosterols (Ryan et al., 2007), antioxidant, carotenoids and vitamin E (Stevenson et al., 2007). Furthermore, pumpkin seeds are rich in minerals such as phosphorus, potassium and iron (Akwaowe et al., 2000).

Pumpkin and its seed have many great health benefits. Pumpkin has a lot of health benefits such as anticancer agents (Elella and Mourad, 2015), antioxidant (Zhao et al., 2015), antimicrobial (Muruganantham et al., 2016) and hypolipidaemic (Song and Sun, 2017). Pumpkin seeds have been recognized as an effective antibacterial (Dissanayake et al., 2018), antioxidant (Kushawaha et al., 2016) and antihyperlipidemic (Kushawaha et al., 2018). It has been reported that pumpkin polysaccharide has hypoglycemic activity on diabetic mice (ShanChen et al., 2019). Furthermore, pumpkin seeds extract showed antidiabetic activity on diabetic rats (Sharma et al., 2013).

In the previous few years, agriculture, food processing and medicine have been increasingly interested in pumpkin and pumpkin-derived products due to the nutritional and health protective of protein and oil from pumpkin seeds, in addition, polysaccharides from pumpkin fruit (Sojak and Glowacki, 2010).

As pumpkin and pumpkin seeds have many nutritional and therapeutic benefits, they are considered important in the food industries. Pumpkin is an economical and rich source of nutrients (Saraswathi et al., 2018). Pumpkin seeds considered as a byproduct of pumpkin fruits, which is cheap and using pumpkin seeds in different food products improve their nutritional value at a lower cost. Therefore, the present research was aimed to study nutritional, sensory evaluation and biological effect on diabetic rats of cakes enhanced with pumpkin fruit (Cucurbita maxima) and its seeds.

\section{Materials and Methods:}

\section{Materials:}

Raw materials required for preparation of cakes such as mature pumpkin, wheat flour ( $72 \%$ extraction), sugar, vegetable oil, eggs, vanilla and baking powder were purchased from local markets in Sharkia Governorate, Egypt. Purchasing of Folin-Ciocalteu reagent, 2,2- diphenyl-1-picrylhydrazyl, gallic acid and alloxan was from Sigma Chemical Company, USA. Kits for blood analysis were purchased from AlkanMedical Division Biocon, Germany. Casein, cellulose, minerals, vitamins were 
purchased from El-Gomhoria Company, Sharkia Governorate, Egypt. All other chemical reagents utilized in the experimental tests of present study were of analytical grade.

\section{Methods:}

\section{Pumpkin and its seeds preparation:}

The first step, pumpkin fruit was washed, peeled, seeds removed (seeds were collected by hand to use later), cut in small pieces and then grinded in laboratory blender to smooth puree. The second step, collected seeds washed with water, then sun dried at $30^{\circ} \mathrm{C}$ for one week according to El-Adawy and Taha, (2001) method. Dried pumpkin seeds were ground by laboratory milling then sieved through a 50-mesh screen. Packing of whole pumpkin seeds flour were in air-tight polyethylene bags and stored at $-18^{\circ} \mathrm{C}$ until use.

\section{Cakes preparation:}

Cakes were prepared as described by Fedha, (2008) with some modifications in amount of vegetable oil and sugar which were reduced from $50 \mathrm{~g}$ to $25 \mathrm{~g}$ as following: wheat flour $(100 \mathrm{~g})$, sugar $(25 \mathrm{~g})$, vegetable oil $(25 \mathrm{~g})$, whole fresh egg (1 egg), baking powder $(2 \mathrm{~g})$, vanilla $(0.2 \mathrm{~g})$ and water as required. The amount of oil in pumpkin seeds was calculated in each treatment then this amount was supplemented with vegetable oil until reached to $25 \mathrm{~g}$. The amount of fresh pumpkin fruit in cakes was calculated based on dry weight of pumpkin, where $10 \%$ of wheat flour was replaced by pumpkin, i.e. $78.7 \mathrm{~g}$ of fresh pumpkin fruit (moisture content $87.3 \%$ ) was added per $90 \mathrm{~g}$ of wheat flour to obtain substitution $10 \%$ of wheat flour by pumpkin based on dry weigh (constant percentage). Cake samples were prepared in six treatments (T1 to T6) with wheat flour, fresh pumpkin fruit (10\% as dry weight) and whole pumpkin seeds flour in the ratio of 100:0:0, 90:10:0, 80:10:10, 70:10:20, 60:10:30 and 50:10:40, respectively. Cake samples were prepared by creaming of vegetable oil and sugar together until fluffy using an electric mixer (Braun-Hm3100, Germany) at medium speed. Then, egg, vanilla and fresh pumpkin fruit (according to which kind of cake prepare) were added and beaten for $5 \mathrm{~min}$. The flour (wheat flour or wheat flour and whole pumpkin seeds flour) and baking powder mixture were gradually added to above mixture and mixed at high speed for 5 min then water was added as required. Cakes placed in oven after poured into a baking pans and baked at a temperature of $180^{\circ} \mathrm{C}$ for $45 \mathrm{~min}$. 
Cakes left to cool for 60 min after baking then packing in polyethylene bags and kept it in the refrigerator for storage until analysis.

\section{Preparation of animals:}

Forty-eight adult male wistar albino rats weighing $130 \pm 5 \mathrm{~g}$ were purchased from the Faculty of Veterinary Medicine, Zagazig University, Sharkia Governorate, Egypt. In individual cages at a temperature of $25^{\circ} \mathrm{C}$ under a 12 hours light/dark cycle rats were lived, furthermore, the food was provided to rats and drinking water ad libitum. Rats were remained for 2 weeks as adaptation period before starting the experiment. Basal diet was prepared as described by Reeves et al., (1993).

\section{Induction of diabetes:}

For inducting rats with diabetes, animals were fasted overnight and diabetes mellitus was induced by a single intraperitoneal injection of freshly prepared solution of alloxan monohydrate $(150 \mathrm{mg} / \mathrm{kg} \mathrm{BW})$ dissolved in physiological saline as described by Famakin et al., (2016). Animals were provided with $5 \%$ solution of glucose for one day only to overcome hypoglycemic effects for the drug. Levels of glucose were measured of rats through tail tipping by glucometer after three days of alloxan administration. Rats were considered diabetic when the fasting glucose level reached $>250$ $\mathrm{mg} / \mathrm{dl}$ according to Zheng et al., (2011), then these rats were separated and used for the current study.

\section{Experimental design:}

The present study consists of eight groups of rats, six rats in each group. Rats were consumed the following diets for three months. Group1 (G1) normal rats consumed the basal diet assigned as negative control group. Other groups were diabetic rats. Group $2(\mathrm{G} 2)$ diabetic rats assigned as positive control and received basal diet. Groups (G3), (G4), (G5), (G6), (G7) and (G8) diabetic rats received basal diet containing $30 \%$ cakes $(30 \%$ of the starch in the basal diet was replaced with cakes) made from wheat flour, pumpkin fruit and whole pumpkin seeds flour in the ratio of 100:0:0, 90:10:0, 80:10:10, 70:10:20, 60:10:30 and 50:10:40, respectively.

Rats body weight were estimated at the starting of the experiment and then weekly for three months (the experiment period). Daily, food intake was 
recorded. After the end of experiment period, rats were fasted for overnight. Using diethyl ether, rats were anesthetized following ethical procedures. Blood samples were collected via cardiac puncture and centrifuged at $3000 \mathrm{rpm}$ for 20 minutes to obtain the serum, which were kept at $-20^{\circ} \mathrm{C}$ until analysis. From sacrificed rats liver, kidney, heart, and spleen were collected and then the weight of these organs was recorded after washed with a physiological saline solution, blotted on filter paper. Pancreas was removed from all experimental rats to be examined microscopically.

\section{Nutritional analysis:}

Proximate analysis value of samples was assessed by using of AOAC, (2012) included moisture, ash, fat, protein and fiber of raw materials and produced cakes. Calculating of carbohydrates was done by difference. The energy value $(\mathrm{EV})$ of different cake treatments was calculated as described by Chaney, (2006) as follows:

Energy $(\mathrm{Kcal} / 100 \mathrm{~g}$ sample $)=4($ protein $\%+$ carbohydrate $\%)+9($ fat $\%)$.

\section{Biochemical analysis:}

Glucose was measured by the method of Trinder, (1969). Determining of insulin was done using the method of Temple et al., (1992). Estimating of total cholesterol (TC), high-density lipoprotein (HDL) and triglycerides (TG) were done by the methods of Richmond, (1973), Burstein et al., (1970) \& Fossati and Prencipe, (1982), respectively. Values of Low-density lipoprotein (LDL) and very low-density lipoprotein (VLDL) have been calculated mathematically by the method of Friedewald et al., (1972). Alanine aminotransferase (ALT) and aspartate aminotransferase (AST) levels were estimated by Reitman and Frankel, (1957) method, while, alkaline phosphatase (ALP) was estimated as described by Klein and Kaufman, (1967). Total protein was measured according to Doumas, (1975) method. Measuring value of albumin was done using Doumas et al., (1971) method. Kidney functions including urea and creatinine were measured using Patton and Crouch, (1977) and Larson, (1972) methods, respectively. 


\section{DPPH radical scavenging assay:}

Examining of the percentage for the DPPH radical scavenging activity was done using 2,2-diphenyl-1-picrylhydrazyl according the method of Brand-Williams et al., (1995) of ethanol extract for raw materials and cakes.

\section{Estimation of total phenolic (TP):}

The amount of total phenolic for raw materials and cakes was estimated calorimetrically using the Folin-Ciocalteu reagent by the method of Singleton et al., (1999). Phenolic values were expressed in terms of gallic acid equivalent (mg GAE/100g sample).

\section{Estimation of total flavonoid (TF):}

Total flavonoid of raw materials and cakes was measured using Zhishen et al., (1999) method. The amount of total flavonoid was expressed as milligram of quercetin equivalents $(\mathrm{QE})$ per $100 \mathrm{~g}$ of sample.

\section{Evaluation of Sensory Attributes:}

The organoleptically evaluation of cakes was estimated for the quality attributes by $20 \mathrm{semi}$ trained panelists from the academic staff members of the Department of Food Science, Faculty of Agriculture, Zagazig University, Egypt. Panelists were asked to evaluate color, taste, odor, texture, appearance and overall acceptability (Sello and Mostafa, 2017).

\section{Histological assay:}

Pancreas from the sacrificed rats was kept in 10\% formalin. Pancreatic tissues were papered and examined under the light microscope as described by Suvarna et al., (2013).

\section{Statistical analysis:}

Data got from the experiments were described as means \pm standard deviation (SD). Findings were exposed to analysis of variance by the "Statistical Package for Social Sciences" (SPSS) version 25. The statistical analysis was done by one-way ANOVA. The differences in the mean were calculated using Duncan's multiple range test among the various samples with a 95\% confidence limit ( $\mathrm{p}<0.05)$ (IBM SPSS, 2017). 


\section{Results and Discussion:}

\section{Nutritional analysis of raw materials:}

The nutritional analysis of the wheat flour, fresh pumpkin fruit and whole pumpkin seeds used in the preparation of cakes is presented in Table (1). Findings demonstrated that a significant difference $(\mathrm{P}<0.05)$ in the nutritional analysis of wheat flour, fresh pumpkin fruit and whole pumpkin seeds flour. Whole pumpkin seeds flour had the highest values of fat $(28.39 \%)$, protein (27.49\%), fiber (17.25\%) and ash (4.68\%) as compared with wheat flour and fresh pumpkin fruit. This result is in accordance with the finding reported by Kindki, (2017) who found that fiber was $18.54 \%$ of whole pumpkin seeds powder as dry basis. Devi et al., (2018) reported that moisture, protein and fat contents of whole pumpkin seeds were 5.53, 28.90 and $31.75 \%$, respectively. It could be observed that wheat flour had the highest amount of carbohydrate (75.28\%), meanwhile, the amount of carbohydrate in whole pumpkin seeds flour and fresh pumpkin fruit were 16.47 and $9.04 \%$, respectively. On the other hand, the highest moisture content was found in fresh pumpkin fruit $(87.3 \%)$ followed by wheat flour and whole pumpkin seeds flour (11.55 and 5.72\%), respectively. Assessment of nutrient content of fresh pumpkin fruit showed that protein, fiber, ash and fat were $1.31,1.16,1.04$ and $0.15 \%$, respectively. Results of moisture, protein and fiber for fresh pumpkin estimated during this study were similar with results reported by Bhat and Bhat, (2013). Also, results exhibited that the nutrient content of wheat flour was protein $(10.15 \%)$, ash $(0.91 \%)$, fat (1.10\%) and fiber (1.01\%). Ahmad et al., (2001) noticed that the nutritional analysis of wheat flour has been estimated by numerous researchers and they found that moisture ranged between $12.5-14.6 \%$ and protein 8.23 $12.71 \%$.

Table 1. Nutritional analysis of wheat flour, fresh pumpkin fruit and whole pumpkin seeds flour (Gram per $100 \mathrm{~g}$ of fresh weight sample).

\begin{tabular}{|l||c|c|c|}
\hline \multirow{2}{*}{ Components \% } & \multicolumn{3}{|c|}{ Raw Materials } \\
\cline { 2 - 4 } & Wheat flour & Fresh pumpkin fruit & Whole pumpkin seeds flour \\
\hline \hline \multirow{2}{*}{ Moisture } & $11.55 \pm 0.92^{\mathrm{b}}$ & $87.3 \pm 2.30^{\mathrm{a}}$ & $5.72 \pm 0.30^{\mathrm{c}}$ \\
\hline Protein & $10.15 \pm 0.80^{\mathrm{b}}$ & $1.31 \pm 0.02^{\mathrm{b}}$ & $27.49 \pm 1.40^{\mathrm{a}}$ \\
\hline Fat & $1.10 \pm 0.02^{\mathrm{b}}$ & $0.15 \pm 0.01^{\mathrm{c}}$ & $28.39 \pm 1.50^{\mathrm{a}}$ \\
\hline Fiber & $1.01 \pm 0.01^{\mathrm{b}}$ & $1.16 \pm 0.02^{\mathrm{b}}$ & $17.25 \pm 0.90^{\mathrm{a}}$ \\
\hline Ash & $0.91 \pm 0.02^{\mathrm{b}}$ & $1.04 \pm 0.04^{\mathrm{b}}$ & $4.68 \pm 0.20^{\mathrm{a}}$ \\
\hline Carbohydrate & $75.28 \pm 2.10^{\mathrm{a}}$ & $9.04 \pm 0.20^{\mathrm{c}}$ & $16.47 \pm 0.80^{\mathrm{b}}$ \\
\hline
\end{tabular}

There is statistically significant in values which have various alphabetical letters in the same line at $(\mathbf{P}<\mathbf{0 . 0 5})$. 


\section{Phenolics, flavonoids and DPPH radical scavenging activity of pumpkin fruit and whole pumpkin seeds:}

As shown in Table (2) pumpkin had higher DPPH radical scavenging percentage (60.22\%) than whole pumpkin seeds (58.44\%). This result is in line with Lotfy et al., (2017) who found that DPPH-scavenging percentage of pumpkin was $61.69 \%$. Data revealed that total phenolic of pumpkin and pumpkin seeds was 32.59 and $31.11 \mathrm{mg}$ gallic acid equivalent/100g sample, respectively. Furthermore, total flavonoid of pumpkin and pumpkin seeds was 12.91 and $12.50 \mathrm{mg}$ quercetin equivalent $/ 100 \mathrm{~g}$ sample, respectively. Singh et al., (2016) estimated that total phenolic of the pumpkin pulp was $33.48 \mathrm{mg}$ GAE/100g sample and total flavonoid was $11.72 \mathrm{mg}$ quercetin equivalent $/ 100 \mathrm{~g}$ sample. Farid et al., (2015) investigated that total phenolic of pumpkin seeds was $32.61 \mathrm{mg}$ gallic acid equivalent $/ 100 \mathrm{~g}$, while, total flavonoid of pumpkin seeds was $19.7 \mathrm{mg}$ quercetin equivalent/100g. Oğuz and Sayaslan, (2019) reported that total phenolic of raw pumpkin seeds was $31.1 \mathrm{mg}$ GAE/100g sample.

Table 2. Phenolics, flavonoids and DPPH radical scavenging activity of pumpkin fruit and its seeds.

\begin{tabular}{||l||c|c|c|}
\hline Raw Materials & DPPH \% & TP mg GAE/100g & TF mg QE/100g \\
\hline \hline Fresh pumpkin fruit & $60.22 \pm 1.20$ & $32.59 \pm 0.40$ & $12.91 \pm 0.21$ \\
\hline Whole pumpkin seeds flour & $58.44 \pm 1.00$ & $31.11 \pm 0.20$ & $12.50 \pm 0.20$ \\
\hline
\end{tabular}

All values are means of 3 determinations \pm SD.

\section{Nutritional analysis of cakes:}

Table (3) demonstrates the mean content of the nutritional analysis of cakes (as fresh weight) prepared with fresh pumpkin fruit and whole pumpkin seeds flour by substituting wheat flour. The incorporation of fresh pumpkin fruit with wheat flour for preparation of cakes (T2) led to a significant increase $(\mathrm{P}<0.05)$ in moisture and fiber contents, whereas, carbohydrate, protein, fat and energy values significantly decreased $(\mathrm{P}<0.05)$ as compared with control cakes (T1). Ash content in cakes also increased with the addition of fresh pumpkin fruit in comparison with control cakes. The highest moisture value (34.97\%) was found in treatment (T5), whereas, the lowest amount $(25.39 \%)$ was in control cakes (T1). This result may be due to the higher water absorption capacity in pumpkin-wheat flour blends compared to wheat flour which is in accordance with the result of See et al., (2007). These results are in line with Păucean and Man, (2014) who stated that addition of pumpkin to the wheat 
flour when preparing the bread led to a significant increase in the final moisture of the bread. Increasing the level of whole pumpkin seeds flour in cakes led to a significant increase $(\mathrm{P}<0.05)$ in moisture content of cakes as compared with cakes enhanced with fresh pumpkin fruit or control cakes. The highest moisture of cakes indicates a hygroscopic influence of the fibers. These results are in agreement with Malkanthi and Umadevi, (2018) who observed that biscuits prepared from the substituting of wheat flour by pumpkin (mixture of fruit and seeds) were significantly increased in moisture content compared to control. Protein, fiber and ash contents in cakes significantly increased $(\mathrm{P}<0.05)$ when the wheat flour replacement with whole pumpkin seeds flour for preparation of cakes comparing with control cakes. These values increased with increasing the level of whole pumpkin seeds flour in cakes. Whereas, carbohydrate, fat and energy levels significantly decreased $(\mathrm{P}<0.05)$ as compared with control cakes. Batista et al., (2018) investigated that increasing pumpkin seeds flour proportions in cupcakes led to a significant increase in protein, fat, fiber and ash except for the carbohydrate, which decreased by increasing the percentage of pumpkin seeds in cupcakes. The highest protein, fiber and ash contents $(12.16$, 5.10 and $3.10 \%)$ were found in cakes containing fresh pumpkin fruit $(10 \%$ as dry weight) and $40 \%$ whole pumpkin seeds flour, respectively. Protein content of cakes in treatments T3, T4, T5 and T6 was 9.9, 20.6, 30.9 and 45.5\% higher than control cakes (T1), respectively. These results probably are due to whole pumpkin seeds flour contain the highest amount of protein, fiber and ash which reach to $27.49,17.25$ and $4.68 \%$, respectively, in comparison with wheat flour and fresh pumpkin fruit. Furthermore, addition of fresh pumpkin fruit to cakes led to a significantly decreased $(\mathrm{P}<0.05)$ in protein content, this finding is in agreement with Ersedo, (2019). This perhaps is attributed to lower protein content in fresh pumpkin fruit $(1.31 \%)$ than wheat flour $(10.15 \%)$. Fat content of cakes significantly decreased $(\mathrm{P}<0.05)$ with the addition of fresh pumpkin fruit or whole pumpkin seeds flour as compared with control cakes because fresh pumpkin fruit has lower amount of fat $(0.15 \%)$ than wheat flour $(1.10 \%)$, in addition, fat content in whole pumpkin seeds flour in each treatments had been used as a fat replacer in cakes. Energy value of the cakes in treatments T2, T3, T4, T5 and T6 was 8.4, 11.7, 15.2, 19.0 and 21.0\% lower than control cakes, respectively. Control cake had the highest energy because it contains a high proportion of carbohydrate \& fat and a low percentage of moisture compared to other treatments.

DPPH radical scavenging activity, total phenolic and total flavonoid for different treatments of cakes are also displayed in Table (3). Data indicated that total phenolic, flavonoids and DPPH radical scavenging percentage significantly increased $(\mathrm{P}<0.05)$ in cakes enhanced with fresh pumpkin fruit or 
cakes containing both fresh pumpkin fruit and different levels of whole pumpkin seeds flour as compared with control cakes. Cakes enhanced with fresh pumpkin fruit and $40 \%$ of whole pumpkin seeds flour were contained the highest total phenolic, flavonoids and DPPH radical scavenging percentage which reached $13.50 \mathrm{mg} \mathrm{GAE} / 100 \mathrm{~g}, 6.50 \mathrm{mg} \mathrm{QE} / 100 \mathrm{~g}$ and $38.15 \%$, respectively. Whereas, control cakes were contained the lowest total phenolic, flavonoids and DPPH radical scavenging percentage. These results are in accordance with Różyło et al., (2014) who found that phenolic and flavonoid compounds were higher in the bread fortified with fresh pumpkin than control bread. Nyam et al., (2013) stated that bread enhanced with pumpkin seeds flour had higher DPPH radical scavenging percentage than control bread.

Table 3. Nutritional analysis of cakes enhanced with pumpkin and its seeds.

\begin{tabular}{|l||c|c|c|c|c|c|}
\hline \multirow{3}{*}{ Components } & \multicolumn{7}{|c|}{ Treatments } \\
\cline { 2 - 8 } & T1 & T2 & T3 & T4 & T5 & T6 \\
\hline \hline Moisture\% & $25.39 \pm 1.30^{\mathrm{e}}$ & $31.04 \pm 1.33^{\mathrm{d}}$ & $32.18 \pm 1.00^{\mathrm{c}}$ & $33.47 \pm 1.10^{\mathrm{b}}$ & $34.97 \pm 1.00^{\mathrm{a}}$ & $34.87 \pm 0.94^{\mathrm{a}}$ \\
\hline Protein \% & $8.36 \pm 0.18^{\mathrm{e}}$ & $7.86 \pm 0.33^{\mathrm{f}}$ & $9.19 \pm 0.22^{\mathrm{d}}$ & $10.08 \pm 0.41^{\mathrm{c}}$ & $10.94 \pm 0.30^{\mathrm{b}}$ & $12.16 \pm 0.39^{\mathrm{a}}$ \\
\hline Fat\% & $15.74 \pm 0.92^{\mathrm{a}}$ & $14.47 \pm 0.91^{\mathrm{b}}$ & $14.17 \pm 0.63^{\mathrm{bc}}$ & $13.92 \pm 0.31^{\mathrm{cd}}$ & $13.58 \pm 0.40^{\mathrm{de}}$ & $13.35 \pm 0.23^{\mathrm{e}}$ \\
\hline Fiber\% & $0.48 \pm 0.02^{\mathrm{f}}$ & $0.78 \pm 0.03^{\mathrm{e}}$ & $1.82 \pm 0.13^{\mathrm{d}}$ & $2.99 \pm 0.10^{\mathrm{c}}$ & $4.05 \pm 0.21^{\mathrm{b}}$ & $5.10 \pm 0.09^{\mathrm{a}}$ \\
\hline Ash\% & $0.57 \pm 0.05^{\mathrm{e}}$ & $0.82 \pm 0.04^{\mathrm{e}}$ & $1.38 \pm 0.19^{\mathrm{d}}$ & $1.92 \pm 0.09^{\mathrm{c}}$ & $2.43 \pm 0.11^{\mathrm{b}}$ & $3.10 \pm 0.03^{\mathrm{a}}$ \\
\hline Carbohydrate\% & $49.46 \pm 1.35^{\mathrm{a}}$ & $45.03 \pm 1.33^{\mathrm{b}}$ & $41.26 \pm 1.20^{\mathrm{c}}$ & $37.62 \pm 0.80^{\mathrm{d}}$ & $34.03 \pm 0.81^{\mathrm{e}}$ & $31.42 \pm 0.40^{\mathrm{f}}$ \\
\hline EV Kcal/100g & $372.94 \pm 3.32^{\mathrm{a}}$ & $341.79 \pm 3.40^{\mathrm{b}}$ & $329.33 \pm 2.50^{\mathrm{c}}$ & $316.08 \pm 2.35^{\mathrm{d}}$ & $302.10 \pm 1.43^{\mathrm{e}}$ & $294.47 \pm 1.44^{\mathrm{f}}$ \\
\hline DPPH \% & $25.58 \pm 1.00^{\mathrm{f}}$ & $28.38 \pm 1.12^{\mathrm{e}}$ & $30.70 \pm 1.00^{\mathrm{d}}$ & $32.90 \pm 1.20^{\mathrm{c}}$ & $35.50 \pm 0.90^{\mathrm{b}}$ & $38.15 \pm 0.71^{\mathrm{a}}$ \\
\hline TP mg GAE/100g & $3.61 \pm 0.36^{\mathrm{f}}$ & $5.93 \pm 0.44^{\mathrm{e}}$ & $7.67 \pm 0.35^{\mathrm{d}}$ & $9.63 \pm 0.33^{\mathrm{c}}$ & $11.50 \pm 0.40^{\mathrm{b}}$ & $13.50 \pm 0.33^{\mathrm{a}}$ \\
\cline { 2 - 8 } TF mg QE/100g & $2.30 \pm 0.12^{\mathrm{f}}$ & $3.30 \pm 0.26^{\mathrm{e}}$ & $3.97 \pm 0.13^{\mathrm{d}}$ & $4.84 \pm 0.20^{\mathrm{c}}$ & $5.51 \pm 0.21^{\mathrm{b}}$ & $6.50 \pm 0.16^{\mathrm{a}}$ \\
\hline
\end{tabular}

There is statistically significant in values which have various alphabetical letters in the same line at $(\mathbf{P}<\mathbf{0 . 0 5})$.

\section{Evaluation of Sensory Attributes:}

Sensory quality of cakes prepared with fresh pumpkin fruit and whole pumpkin seeds flour are presented in Table (4). The present study showed that no significant changes $(\mathrm{P}<0.05)$ observed among control cakes and all kinds of cakes in appearance, odor and texture scores. The scores of overall acceptability, color and taste of cakes significantly increased $(\mathrm{P}<0.05)$ as compared with control cakes. Cakes enhanced with fresh pumpkin and $40 \%$ whole pumpkin seeds flour were recorded the highest scores for all quality attributes. Findings are in agreement with Różyło et al., (2014) who showed that bread made from the substituting of wheat flour with up to $10 \%$ pumpkin was evaluated the most acceptable as compared with control bread. Batista et 
al., (2018) reported that the use of pumpkin seeds flour in the making of cupcakes up to $50 \%$ was considered the best percentage.

Table 4: Effect of pumpkin and its seeds on the sensory evaluation of cakes.

\begin{tabular}{|c||c|c|c|c|c|c|}
\hline \hline Treatments & $\begin{array}{c}\text { Appearance } \\
(\mathbf{1 0 )}\end{array}$ & $\begin{array}{c}\text { Color } \\
(\mathbf{1 0 )}\end{array}$ & $\begin{array}{c}\text { Taste } \\
(\mathbf{1 0 )}\end{array}$ & $\begin{array}{c}\text { Odor } \\
(\mathbf{1 0})\end{array}$ & $\begin{array}{c}\text { Texture } \\
(\mathbf{1 0 )}\end{array}$ & $\begin{array}{c}\text { Overall } \\
\text { acceptability (10) }\end{array}$ \\
\hline \hline $\mathbf{T}_{\mathbf{1}}$ & $8.43 \pm 0.46^{\mathrm{a}}$ & $8.28 \pm 0.43^{\mathrm{b}}$ & $8.20 \pm 0.42^{\mathrm{b}}$ & $8.49 \pm 0.40^{\mathrm{a}}$ & $8.51 \pm 0.41^{\mathrm{a}}$ & $8.50 \pm 0.56^{\mathrm{b}}$ \\
\hline $\mathbf{T}_{\mathbf{2}}$ & $8.50 \pm 0.42^{\mathrm{a}}$ & $8.70 \pm 0.56^{\mathrm{a}}$ & $8.58 \pm 0.44^{\mathrm{a}}$ & $8.60 \pm 0.32^{\mathrm{a}}$ & $8.69 \pm 0.54^{\mathrm{a}}$ & $8.72 \pm 0.45^{\mathrm{a}}$ \\
\hline $\mathbf{T}_{\mathbf{3}}$ & $8.65 \pm 0.41^{\mathrm{a}}$ & $8.80 \pm 0.35^{\mathrm{a}}$ & $8.62 \pm 0.36^{\mathrm{a}}$ & $8.70 \pm 0.57^{\mathrm{a}}$ & $8.72 \pm 0.32^{\mathrm{a}}$ & $8.75 \pm 0.34^{\mathrm{a}}$ \\
\hline $\mathbf{T}_{\mathbf{4}}$ & $8.72 \pm 0.42^{\mathrm{a}}$ & $8.85 \pm 0.43^{\mathrm{a}}$ & $8.72 \pm 0.33^{\mathrm{a}}$ & $8.75 \pm 0.41^{\mathrm{a}}$ & $8.76 \pm 0.21^{\mathrm{a}}$ & $8.81 \pm 0.40^{\mathrm{a}}$ \\
\hline $\mathbf{T}_{\mathbf{5}}$ & $8.78 \pm 0.22^{\mathrm{a}}$ & $8.91 \pm 0.42^{\mathrm{a}}$ & $8.77 \pm 0.41^{\mathrm{a}}$ & $8.78 \pm 0.34^{\mathrm{a}}$ & $8.79 \pm 0.26^{\mathrm{a}}$ & $8.85 \pm 0.43^{\mathrm{a}}$ \\
\hline $\mathbf{T}_{\mathbf{6}}$ & $8.81 \pm 0.34^{\mathrm{a}}$ & $8.93 \pm 0.39^{\mathrm{a}}$ & $8.80 \pm 0.42^{\mathrm{a}}$ & $8.81 \pm 0.41^{\mathrm{a}}$ & $8.80 \pm 0.31^{\mathrm{a}}$ & $8.91 \pm 0.41^{\mathrm{a}}$ \\
\hline
\end{tabular}

There is statistically significant in values which have various alphabetical letters in the same column at $(\mathbf{P}<\mathbf{0 . 0 5})$.

\section{Effect of feeding diabetic rats with cakes enhanced with pumpkin and its seeds on body weight gain (BWG), food intake (FI) and feed efficiency ratio (FER):}

Results indicated that there was significantly decreased $(\mathrm{P}<0.05)$ in BWG, FI and FER of diabetic rats (G2) in comparison with normal control rats (G1) (Table 5). The lower weight of diabetic rats perhaps is attribute to the loss or deterioration of structural proteins (Ramesh and Pugalendi, 2006). These findings are in agreement with the results of Abul-Fadl et al., (2016) who found that significantly decreased in BWG of diabetic rats as compared with negative control rats. Also, these results are in agreement with Alsuhaibani and Al-Kuraieef, (2018) who noticed that body weight gain, food intake and feed e ciency ratio were decreased in diabetic rats in comparison with negative control rats. Results indicated that a significant improve $(\mathrm{P}<0.05)$ was observed in BWG, FI and FER of diabetic rats consumed cakes enhanced with fresh pumpkin or cakes containing both fresh pumpkin and different levels of whole pumpkin seeds as compared with control diabetic rats or diabetic rats consumed control cakes. These results probably are due to the efficiency of pumpkin and its seeds to reduce glucose level in the blood of rats. The best improvement was found in diabetic rats consumed cakes containing fresh pumpkin and $40 \%$ whole pumpkin seeds. Chen et al., (2019) found that diabetic mice treated with pumpkin polysaccharides showed significantly increased in body weight compared to positive control group. Sharma et al., (2013) estimated that treatment with pumpkin seeds extract was improved the BWG of treated rats compared with diabetic rats. 
Table 5: Effect of feeding diabetic rats with cakes enhanced with pumpkin and its seeds on BWG, FI and FER.

\begin{tabular}{|c|c|c|c|c|}
\hline Groups & BWG (g) & BWG (\%) & FI (g/rat/3months) & FER \\
\hline \hline G1 & $95.88 \pm 1.60^{\mathrm{a}}$ & $73.75 \pm 1.60^{\mathrm{a}}$ & $1692.00 \pm 3.30^{\mathrm{a}}$ & $0.057 \pm 0.002^{\mathrm{a}}$ \\
\hline G2 & $44.23 \pm 1.10^{\mathrm{h}}$ & $35.38 \pm 1.00^{\mathrm{g}}$ & $1539.00 \pm 3.40^{\mathrm{g}}$ & $0.029 \pm 0.001^{\mathrm{f}}$ \\
\hline G3 & $53.00 \pm 1.01^{\mathrm{g}}$ & $39.26 \pm 1.12^{\mathrm{f}}$ & $1620.00 \pm 2.10^{\mathrm{f}}$ & $0.033 \pm 0.001^{\mathrm{ef}}$ \\
\hline G4 & $60.30 \pm 1.60^{\mathrm{f}}$ & $46.03 \pm 1.23^{\mathrm{e}}$ & $1661.40 \pm 2.30^{\mathrm{e}}$ & $0.036 \pm 0.001^{\mathrm{de}}$ \\
\hline G5 & $67.20 \pm 1.40^{\mathrm{e}}$ & $51.69 \pm 1.10^{\mathrm{d}}$ & $1669.50 \pm 3.60^{\mathrm{de}}$ & $0.040 \pm 0.002^{\mathrm{cd}}$ \\
\hline G6 & $73.50 \pm 1.10^{\mathrm{d}}$ & $56.11 \pm 1.30^{\mathrm{c}}$ & $1674.00 \pm 3.70^{\mathrm{cd}}$ & $0.044 \pm 0.001^{\mathrm{bc}}$ \\
\hline G7 & $79.20 \pm 1.02^{\mathrm{c}}$ & $60.92 \pm 1.41^{\mathrm{b}}$ & $1679.40 \pm 2.10^{\mathrm{bc}}$ & $0.047 \pm 0.002^{\mathrm{b}}$ \\
\hline G8 & $80.00 \pm 1.50^{\mathrm{b}}$ & $61.07 \pm 1.10^{\mathrm{b}}$ & $1683.00 \pm 2.20^{\mathrm{b}}$ & $0.048 \pm 0.003^{\mathrm{b}}$ \\
\hline
\end{tabular}

There is statistically significant in values which have various alphabetical letters in the same column at $(P<0.05)$ BWG: Body weight gain. $\quad$ FI: Food intake. FER: Feed efficiency ratio.

\section{Effect of feeding diabetic rats with cakes enhanced with pumpkin and its seeds on relative weight of organs:}

Data in Table (6) showed that a significant decrease $(\mathrm{P}<0.05)$ was noticed in relative weight of organs for diabetic rats compared with negative control rats. These results perhaps are due to reduce (BWG), (FI) and (FER) of diabetic rats as compared with normal rats. Treatment diabetic rats with cakes containing fresh pumpkin or cakes enhanced with both fresh pumpkin and different levels of whole pumpkin seeds led to a significant improve $(\mathrm{P}<0.05)$ in relative weight of liver, kidney, spleen and heart compared with diabetic rats (G2) or diabetic rats fed with control cakes (G3). These results probably are due to the improvement of nutritional indicators of diabetic rats which were fed with cakes enhanced with pumpkin (fruit or fruit and its seeds).

Table 6: Effect of feeding diabetic rats with cakes enhanced with pumpkin and its seeds on relative weight of organs (g).

\begin{tabular}{|c|c|c|c|c|}
\hline Groups & Liver & Kidney & Spleen & Heart \\
\hline$\overline{\text { G1 }}$ & $\overline{5.07 \pm 0.20^{\mathrm{a}}}$ & $1.15 \pm 0 . \cdot r^{\mathrm{a}}$ & $0.45 \pm 0.0^{r^{a}}$ & $\cdot .56 \pm 0.0 r^{\mathrm{a}}$ \\
\hline G2 & $3.13 \pm 0.11^{\mathrm{f}}$ & $\cdot .71 \pm 0 . \cdot 1^{\mathrm{d}}$ & $0.23 \pm 0.01^{f}$ & $\cdot .35 \pm 0.01^{\mathrm{e}}$ \\
\hline G3 & $3.15 \pm 0.14^{f}$ & $\cdot .73 \pm 0 . \cdot 2^{\mathrm{d}}$ & $\cdot .24 \pm 0.01^{\mathrm{f}}$ & $\cdot .36 \pm 0.0)^{\mathrm{de}}$ \\
\hline G4 & $3.50 \pm .0 .11^{\mathrm{e}}$ & $\cdot .86 \pm 0 \cdot \mu^{c}$ & $\cdot .29 \pm 0.0 r^{\mathrm{e}}$ & $\cdot .42 \pm 0.0^{r^{\mathrm{cd}}}$ \\
\hline G5 & $3.80 \pm 0.10^{\mathrm{d}}$ & $\cdot .90 \pm 0.1^{b c}$ & $\cdot .33 \pm 0 . r^{d}$ & $\cdot .44 \pm 0.0)^{b c}$ \\
\hline G6 & $4.15 \pm 0.16^{\mathrm{c}}$ & $\cdot .93 \pm 0 . \cdot r^{b c}$ & $\cdot .36 \pm 0 . \cdot 2^{\mathrm{c}}$ & $\cdot .47 \pm 0.0)^{b c}$ \\
\hline G7 & $4.50 \pm 0.15^{b}$ & $\cdot .96 \pm 0 . \cdot 1^{b}$ & $\cdot .37 \pm 0.)^{b c}$ & $\cdot .48 \pm 0.02^{\mathrm{bc}}$ \\
\hline G8 & $4.56 \pm 0.1)^{b}$ & $\cdot .97 \pm 0 . \cdot)^{b}$ & $\cdot .38 \pm 0 \cdot \cdot r^{b}$ & $\cdot .49 \pm 0.0 r^{b}$ \\
\hline
\end{tabular}

There is statistically significant in values which have various alphabetical letters in the same column at $(\mathbf{P}<\mathbf{0 . 0 5})$. 


\section{Effect of feeding diabetic rats with cakes enhanced with pumpkin and its seeds on glucose and insulin values:}

Glucose and insulin values of diabetic rats fed with control cakes, cakes containing fresh pumpkin and cakes enhanced with both fresh pumpkin and different levels of whole pumpkin seeds are clarified in Table (7). Results indicated that a significant hyperglycemia $(\mathrm{P}<0.05)$ and lower insulin level were observed in diabetic rats (G2) and diabetic rats consumed control cakes (G3) compared to normal rats (G1). These results are in line with Khalil, (2004) who showed that plasma glucose value was significantly increased in diabetic rats and this was associated with decrease plasma insulin level. These findings probably are due to the cytotoxic factor of alloxan that lead to a high reduce of the $\beta$-cells in pancreas of diabetic rats in comparison with control rats. Data revealed that there was significantly improved $(\mathrm{P}<0.05)$ in glucose and insulin values of diabetic rats consumed cakes enhanced with fresh pumpkin (G4) compared with diabetic rats (G2) or diabetic rats consumed control cakes (G3) and it reached to $224.2 \mathrm{mg} / \mathrm{dl}$ and $2.83 \mu \mathrm{IU} / \mathrm{ml}$, respectively. These findings perhaps are due to pumpkin fruit has higher amount of phenolic and flavonoid compounds than wheat flour. Similar result was observed by Chen et al., (2019) who noticed that mice treated with pumpkin polysaccharides showed a significant decrease in glucose value compared to diabetic mice. Diabetic rats consumed cakes enhanced with both fresh pumpkin and different levels of whole pumpkin seeds showed that a significant improve $(\mathrm{P}<0.05)$ in their glucose and insulin levels in comparison with diabetic rats or diabetic rats consumed control cakes and this improvement increased with increasing the level of whole pumpkin seeds in cakes. These results probably are due to pumpkin seeds have higher levels of phenolic and flavonoid compounds compared to wheat flour. The best levels of glucose and insulin were in diabetic rats fed with cakes enhanced with both fresh pumpkin and the highest level of pumpkin seeds $(40 \%)$ where the level of glucose reduced by $67 \%$, while, the level of insulin increased by $53 \%$ in comparison with diabetic rats. Moreover, this treatment brought down the elevated values of glucose and increased the low values of insulin in diabetic rats to nearly normal values. Sharma et al., (2013) indicated that diabetic rats treated with pumpkin seeds extract showed a significant reduce in level of glucose and increase in insulin level. 
Table 7: Effect of feeding diabetic rats with cakes enhanced with pumpkin and its seeds on glucose and insulin values.

\begin{tabular}{|c||c|c|}
\hline Groups & Glucose $\mathbf{~ m g} / \mathbf{d l}$ & Insulin $\boldsymbol{\mu I U} / \mathbf{m l}$ \\
\hline \hline G1 & $90.00 \pm 1.20^{\mathrm{h}}$ & $4.00 \pm 0.11^{\mathrm{a}}$ \\
\hline G2 & $280.3 \pm 2.21^{\mathrm{a}}$ & $2.50 \pm 0.02^{\mathrm{e}}$ \\
\hline G3 & $276.2 \pm 2.00^{\mathrm{b}}$ & $2.52 \pm 0.04^{\mathrm{e}}$ \\
\hline G4 & $224.2 \pm 1.93^{\mathrm{c}}$ & $2.83 \pm 0.03^{\mathrm{de}}$ \\
\hline G5 & $191.3 \pm 1.21^{\mathrm{d}}$ & $3.11 \pm 0.03^{\mathrm{cd}}$ \\
\hline G6 & $158.0 \pm 1.05^{\mathrm{e}}$ & $3.33 \pm 0.02^{\mathrm{bc}}$ \\
\hline G7 & $124.1 \pm 1.22^{\mathrm{f}}$ & $3.59 \pm 0.02^{\mathrm{ab}}$ \\
\hline G8 & $92.4 \pm 1.20^{\mathrm{g}}$ & $3.83 \pm 0.03^{\mathrm{a}}$ \\
\hline
\end{tabular}

There is statistically significant in values which have various alphabetical letters in the same column at $(\mathbf{P}<\mathbf{0 . 0 5})$.

\section{Effect of feeding diabetic rats with cakes enhanced with pumpkin and its seeds on lipid profile:}

Results of lipid profile are clarified in Table (8). Diabetic rats (G2) revealed that significantly increased $(\mathrm{P}<0.05)$ in $\mathrm{TG}, \mathrm{TC}, \mathrm{LDL}$ and VLDL values, whilst, significantly reduced $(\mathrm{P}<0.05)$ was observed in HDL level compared to control rats $(\mathrm{G} 1)$. Feeding diabetic rats with cakes enhanced with fresh pumpkin or cakes containing both fresh pumpkin and different levels of whole pumpkin seeds led to a significant decrease $(\mathrm{P}<0.05)$ in $\mathrm{TG}, \mathrm{TC}, \mathrm{LDL}$ and VLDL values as well as a significant increase $(\mathrm{P}<0.05)$ in level of HDL as compared to diabetic rats or diabetic rats consumed control cakes. Lipid reducing effects for cakes which contain whole pumpkin seeds probably are due to its fibers. Findings indicated that the improvement in lipid profile increased by increasing the level of whole pumpkin seeds in cakes. The present research revealed that the best results of lipid profile were noticed in diabetic rats fed with cakes enhanced with fresh pumpkin and $40 \%$ of whole pumpkin seeds. This treatment reduced the values of TG, TC, LDL and VLDL by 56.9, 53.8, 74.6 and $56.9 \%$, respectively, and increased the level of HDL by $52.3 \%$ compared to diabetic rats. Furthermore, this treatment minimized the increased values of TG, TC, LDL and VLDL, while, increased the low value of HDL in rats with diabetes to nearly normal values. These results are in agreement with Chen et al., (2019) who showed that pumpkin polysaccharides significantly reduced TG, TC \& LDL levels and improved HDL level in diabetic mice. Also, these findings are in line with Sharma et al., (2013) who noticed that values of TC, TG, LDL and VLDL significantly decreased and HDL significantly 
increased in animals treated with different extracts of pumpkin seeds compared to diabetic animals.

Table 8: Effect of feeding diabetic rats with cakes enhanced with pumpkin and its seeds on lipid profile (mg/dl).

\begin{tabular}{||c|c|c|c|c|c|}
\hline Groups & TG & TC & HDL & LDL & VLDL \\
\hline \hline G1 & $88.00 \pm 1.20^{\mathrm{g}}$ & $100.00 \pm 1.10^{\mathrm{g}}$ & $49.20 \pm 1.00^{\mathrm{a}}$ & $33.20 \pm 0.80^{\mathrm{h}}$ & $17.60 \pm 0.52^{\mathrm{g}}$ \\
\hline G2 & $211.50 \pm 3.12^{\mathrm{a}}$ & $225.00 \pm 2.20^{\mathrm{a}}$ & $31.00 \pm 0.90^{\mathrm{g}}$ & $151.70 \pm 2.30^{\mathrm{a}}$ & $42.30 \pm 1.00^{\mathrm{a}}$ \\
\hline \multirow{2}{*}{ G3 } & $211.00 \pm 3.21^{\mathrm{a}}$ & $224.40 \pm 2.32^{\mathrm{a}}$ & $31.30 \pm 0.80^{\mathrm{g}}$ & $150.90 \pm 2.92^{\mathrm{b}}$ & $42.20 \pm 0.62^{\mathrm{a}}$ \\
\hline G4 & $179.78 \pm .2 .21^{\mathrm{b}}$ & $193.50 \pm 2.24^{\mathrm{b}}$ & $34.72 \pm 0.50^{\mathrm{f}}$ & $122.82 \pm 2.36^{\mathrm{c}}$ & $35.96 \pm 0.46^{\mathrm{b}}$ \\
\hline G5 & $157.57 \pm 2.20^{\mathrm{c}}$ & $170.40 \pm 2.23^{\mathrm{c}}$ & $37.82 \pm 0.60^{\mathrm{e}}$ & $101.07 \pm 1.61^{\mathrm{d}}$ & $31.51 \pm 0.31^{\mathrm{c}}$ \\
\hline G6 & $135.06 \pm 2.23^{\mathrm{d}}$ & $148.50 \pm 1.30^{\mathrm{d}}$ & $40.72 \pm 0.22^{\mathrm{d}}$ & $80.77 \pm 1.10^{\mathrm{e}}$ & $27.01 \pm 0.40^{\mathrm{d}}$ \\
\hline G7 & $113.15 \pm 1.65^{\mathrm{e}}$ & $126.00 \pm 1.23^{\mathrm{e}}$ & $44.02 \pm 0.60^{\mathrm{c}}$ & $59.35 \pm 0.89^{\mathrm{f}}$ & $22.63 \pm 0.42^{\mathrm{e}}$ \\
\hline G8 & $91.20 \pm 1.20^{\mathrm{f}}$ & $104.00 \pm 1.15^{\mathrm{f}}$ & $47.22 \pm 0.41^{\mathrm{b}}$ & $38.54 \pm 0.53^{\mathrm{g}}$ & $18.24 \pm 0.48^{\mathrm{f}}$ \\
\hline
\end{tabular}

There is statistically significant in values which have various alphabetical letters in the same column at $(\mathbf{P}<\mathbf{0 . 0 5})$.

\section{Effect of feeding diabetic rats with cakes enhanced with pumpkin and its seeds on liver function parameters:}

Aspartate aminotransferase, alanine aminotransferase and alkaline phosphatase of diabetic rats were significantly increased $(\mathrm{P}<0.05)$ as compared with normal rats (Table 9). Results revealed that rats with diabetes treated with control cakes showed that non-significant decrease $(\mathrm{P}<0.05)$ in aspartate aminotransferase, alanine aminotransferase and alkaline phosphatase as compared to diabetic rats. Whereas, diabetic rats treated with cakes containing fresh pumpkin or cakes enhanced with both fresh pumpkin and various levels of whole pumpkin seeds displayed that a significant decrease $(\mathrm{P}<0.05)$ in values of aspartate aminotransferase, alanine aminotransferase and alkaline phosphatase in comparison with diabetic rats. These results perhaps are due to pumpkin and its seeds have higher amount of phenolic and flavonoid compounds than wheat flour which protect liver cell from damage. Sharma et al., (2013) reported similar results of the increased values of aspartate aminotransferase, alanine aminotransferase and alkaline phosphatase in diabetic rats comparing with control rats, while, rats treated with various extracts of pumpkin seeds (Cucurbita maxima) showed significantly reduced in aspartate aminotransferase, alanine aminotransferase and alkaline phosphatase values compared with diabetic rats. Results showed that the improvement in liver functions increased by increasing the level of whole pumpkin seeds in cakes. Diabetic rats consumed cakes enhanced with fresh pumpkin and $40 \%$ of whole 
pumpkin seeds reduced the levels of aspartate aminotransferase, alanine aminotransferase and alkaline phosphatase by 54.6, 53.0 and $31.8 \%$, respectively, comparing with diabetic rats. Whilst, a significant reduce $(\mathrm{P}<0.05)$ was showed in total protein and albumin in animals with diabetes compared with control animals. The present study showed that non-significantly increased $(\mathrm{P}<0.05)$ in total protein and albumin levels in diabetic rats treated with control and fresh pumpkin cakes as compared to diabetic rats. But diabetic rats treated with cakes containing both fresh pumpkin and different levels of whole pumpkin seeds recorded significantly increased $(\mathrm{P}<0.05)$ in total protein and albumin compared with diabetic rats. The increase in total protein and albumin values were increased with increasing the level of whole pumpkin seeds in cakes. Total protein $(6.94 \mathrm{~g} / \mathrm{dl})$ and albumin $(3.92 \mathrm{~g} / \mathrm{dl})$ values restored to normal values in diabetic rats treated with cakes enhanced with fresh pumpkin and $40 \%$ of whole pumpkin seeds.

Table 9: Effect of feeding diabetic rats with cakes enhanced with pumpkin and its seeds on liver function parameters.

\begin{tabular}{|c||c|c|c|c|c|}
\hline Groups & AST (U/L) & ALT (U/L) & ALP (U/L) & Protein (g/dl) & Albumin (g/dl) \\
\hline \hline G1 & $35.00 \pm 1.00^{\mathrm{f}}$ & $25.00 \pm 0.93^{\mathrm{g}}$ & $79.80 \pm 1.32^{\mathrm{g}}$ & $7.20 \pm 0.30^{\mathrm{a}}$ & $4.10 \pm 0.14^{\mathrm{a}}$ \\
\cline { 2 - 6 } & $79.50 \pm 1.12^{\mathrm{a}}$ & $56.00 \pm 1.20^{\mathrm{a}}$ & $120.00 \pm 2.18^{\mathrm{a}}$ & $5.00 \pm 0.21^{\mathrm{e}}$ & $2.90 \pm 0.04^{\mathrm{f}}$ \\
\cline { 2 - 6 } G2 & $79.00 \pm 1.21^{\mathrm{a}}$ & $55.50 \pm 1.10^{\mathrm{a}}$ & $119.00 \pm 2.26^{\mathrm{a}}$ & $5.10 \pm 0.22^{\mathrm{e}}$ & $2.92 \pm 0.05^{\mathrm{f}}$ \\
\cline { 2 - 6 } G3 & $70.36 \pm .1 .31^{\mathrm{b}}$ & $49.84 \pm 0.90^{\mathrm{b}}$ & $111.84 \pm 2.24^{\mathrm{b}}$ & $5.33 \pm 0.25^{\mathrm{de}}$ & $3.06 \pm 0.10^{\mathrm{ef}}$ \\
\hline \multirow{2}{*}{ G4 } & $61.77 \pm 1.10^{\mathrm{c}}$ & $44.00 \pm 0.71^{\mathrm{c}}$ & $104.00 \pm 1.53^{\mathrm{c}}$ & $5.80 \pm 0.31^{\mathrm{cd}}$ & $3.30 \pm 0.11^{\mathrm{de}}$ \\
\hline G5 & $53.07 \pm 1.00^{\mathrm{d}}$ & $38.00 \pm 0.80^{\mathrm{d}}$ & $96.74 \pm 1.16^{\mathrm{d}}$ & $6.19 \pm 0.23^{\mathrm{bc}}$ & $3.48 \pm 0.10^{\mathrm{cd}}$ \\
\hline G6 & $45.00 \pm 0.65^{\mathrm{e}}$ & $32.20 \pm 0.73^{\mathrm{e}}$ & $89.28 \pm 1.12^{\mathrm{e}}$ & $6.59 \pm 0.29^{\mathrm{ab}}$ & $3.68 \pm 0.12^{\mathrm{bc}}$ \\
\hline G7 & $36.07 \pm 0.60^{\mathrm{f}}$ & $26.32 \pm 0.80^{\mathrm{f}}$ & $81.84 \pm 1.01^{\mathrm{f}}$ & $6.94 \pm 0.33^{\mathrm{a}}$ & $3.92 \pm 0.13^{\mathrm{ab}}$ \\
\hline G8 & &
\end{tabular}

There is statistically significant in values which have various alphabetical letters in the same column at $(\mathbf{P}<\mathbf{0 . 0 5})$.

\section{Effect of feeding diabetic rats with cakes enhanced with pumpkin and its seeds on kidney function parameters:}

A significant increase $(\mathrm{P}<0.05)$ was demonstrated in kidney profile of rats with diabetes comparing with control rats (Table 10). The present data clarified that non-significant difference between diabetic rats and diabetic rats treated with control cakes. Diabetic rats consumed cakes enhanced with fresh pumpkin or cakes containing both fresh pumpkin and different levels of whole pumpkin seeds recorded that a significant decrease $(\mathrm{P}<0.05)$ in urea and creatinine values compared with diabetic rats. Ramadan et. al., (2016) found that rats received high fat diet with pumpkin seeds oil showed significantly 
reduced in kidney function tests compared with high fat diet treated rats. The decrease in urea and creatinine values were increased with increasing the level of whole pumpkin seeds in cakes. Urea and creatinine levels restored to normal levels in diabetic rats treated with cakes containing fresh pumpkin and $40 \%$ of whole pumpkin seeds.

Table 10: Effect of feeding diabetic rats with cakes enhanced with pumpkin and its seeds on kidney function parameters $(\mathrm{mg} / \mathrm{dl})$.

\begin{tabular}{|c||c|c|}
\hline Groups & Urea & Creatinine \\
\hline \hline G1 & $35.00 \pm 1.10^{\mathrm{f}}$ & $0.69 \pm 0.03^{\mathrm{f}}$ \\
\hline G2 & $73.50 \pm 1.12^{\mathrm{a}}$ & $1.80 \pm 0.10^{\mathrm{a}}$ \\
\hline G3 & $73.00 \pm 1.22^{\mathrm{a}}$ & $1.78 \pm 0.21^{\mathrm{a}}$ \\
\hline G4 & $65.42 \pm 1.00^{\mathrm{b}}$ & $1.58 \pm 0.24^{\mathrm{b}}$ \\
\hline G5 & $58.07 \pm 1.10^{\mathrm{c}}$ & $1.40 \pm 0.12^{\mathrm{c}}$ \\
\hline G6 & $51.00 \pm 0.83^{\mathrm{d}}$ & $1.18 \pm 0.14^{\mathrm{d}}$ \\
\hline G7 & $43.17 \pm 0.77^{\mathrm{e}}$ & $0.98 \pm 0.12^{\mathrm{e}}$ \\
\hline G8 & $36.02 \pm 0.52^{\mathrm{f}}$ & $0.77 \pm 0.08^{\mathrm{f}}$ \\
\hline
\end{tabular}

There is statistically significant in values which have various alphabetical letters in the same column at $(\mathbf{P}<\mathbf{0 . 0 5})$.

\section{Histopathological examination:}

Histological examination of the section of pancreas indicated that normal control rats had normal histomorphological structure of exocrine and endocrine part of the pancreas (Photo.1). Whereas, pancreas of diabetic rats showed degenerative changes within pancreatic acini which represented mostly by fatty degeneration within epithelial lining acini. Islets cells revealed degenerative and apoptotic changes beside presence some inflammatory cells. Moreover, decrease number and size of endocrine cells were also seen (Photo.2). These results are in accordance with Elkotby et al., (2018) who reported that islets size and $\beta$-cells number decreased in pancreatic tissues of rats with diabetes. Pancreatic islets of diabetic rats consumed control cakes appeared comparatively smaller in size and few in number with degenerative changes of some cells which represented mostly by acute cell swelling. In addition, perivascular inflammatory cells infiltration were also detected (Photo. 3). While, pancreatic islets of diabetic rats fed with cakes containing fresh pumpkin revealed degenerative and earily necrotic changes in some cells. The exocrine pancreas revealed normal acini with mildly to moderately congested pancreatic blood vessels, periductal and interstitial lymphocytic infiltration and cystic dilatation of the pancreatic ducts (Photo. 4). Pancreas of diabetic rats fed 
with cakes containing fresh pumpkin and $10 \%$ whole pumpkin seeds showed congested pancreatic blood vessels, cystic dilatation of pancreatic ducts and normal pancreatic acini. Some of the islets cells showed decrease cellular population with degeneration of some beta cells. Other islets cells observed normal population of cells including alpha, beta and delta cells (Photo. 5). Section from pancreas of diabetic rats consumed cakes containing fresh pumpkin and $20 \%$ whole pumpkin seeds showed apparently normal histomorphological structure of exocrine and endocrine parts. Nevertheless, congested pancreatic blood vessels were also seen (Photo. 6). The endocrine part of pancreas of diabetic rats fed with cakes containing fresh pumpkin and $30 \%$ whole pumpkin seeds showed increase vascularization between regenerated islets cells. Whereas, pancreatic blood vessels showed congestion with perivascular edema and hemorrhage (Photo. 7). Majority of pancreatic islets of diabetic rats fed with cakes containing fresh pumpkin and $40 \%$ whole pumpkin seeds were large in size or of normal sizes with apparently normal active cellular contents. While, the exocrine pancreas showed apparently normal pancreatic acini (Photo. 8). These results perhaps are due to pumpkin and its seeds have antioxidant activity which led to increase the number of $\beta$ cells by enhancing the repair and regeneration of $\beta$-cells and protect cell membranes from oxidative damage. Bharti et al., (2013) demonstrated that diabetic rats consumed tocopherol fraction of raw pumpkin seeds significantly increased in the number of islets.

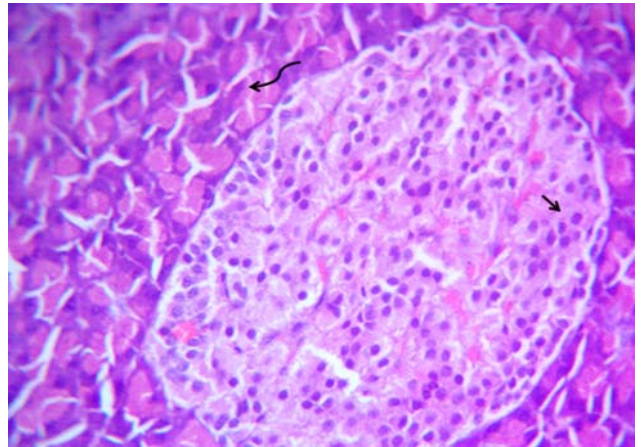

Photo. 1 (G1): Photomicrograph of rat's pancreas showing normal endocrine islets cells populations (arrow) and other pancreatic parenchymal and stromal cells (curved arrow) H\&E (X400).

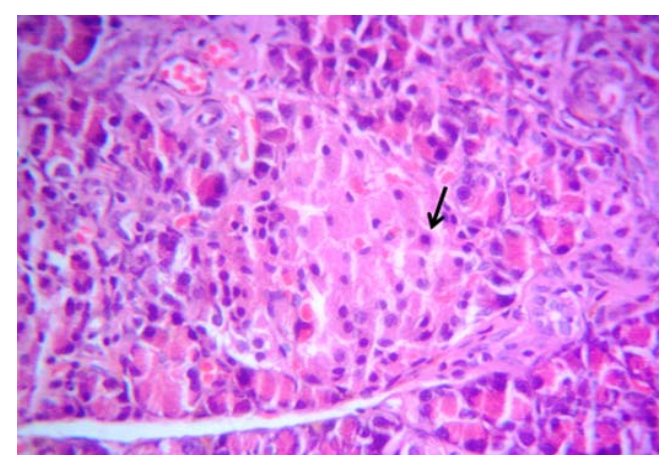

Photo. 2 (G2): Photomicrograph of rat's pancreas showing small sized islets suffered from loss of cellularity populations, degenerative and apoptotic changes (arrow) of some islets cells H\&E (X400). 


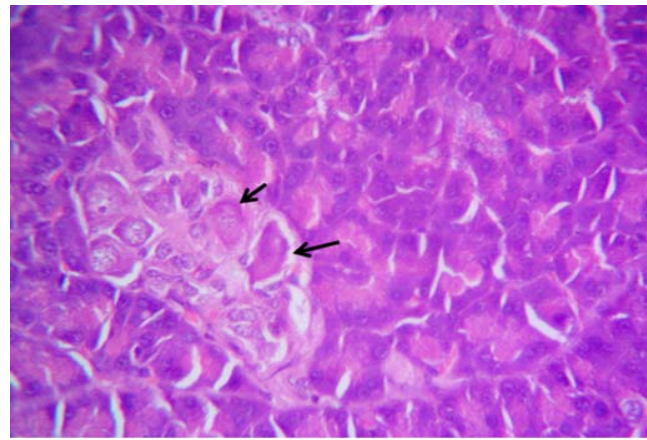

Photo. 3 (G3): Photomicrograph of rat's pancreas showing degenerative changes mostly in the form of acute cell swelling (arrow) within islets cells $\mathrm{H} \& \mathrm{E}$ (X400).

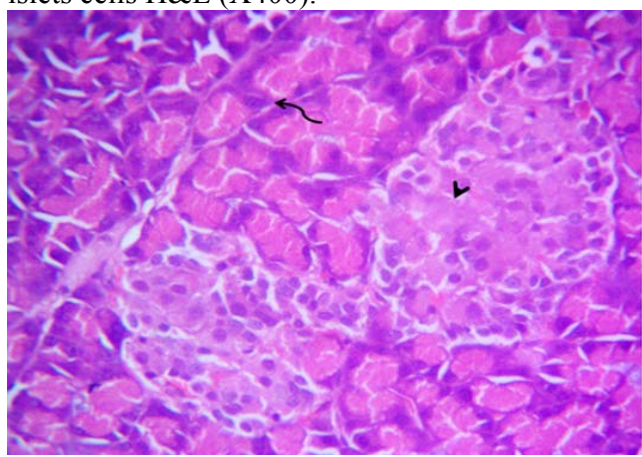

Photo. 5 (G5): Photomicrograph of rat's pancreas showing normal pancreatic acini (curved arrow) with degeneration of some islets cells (arrow head) H\&E (X400).

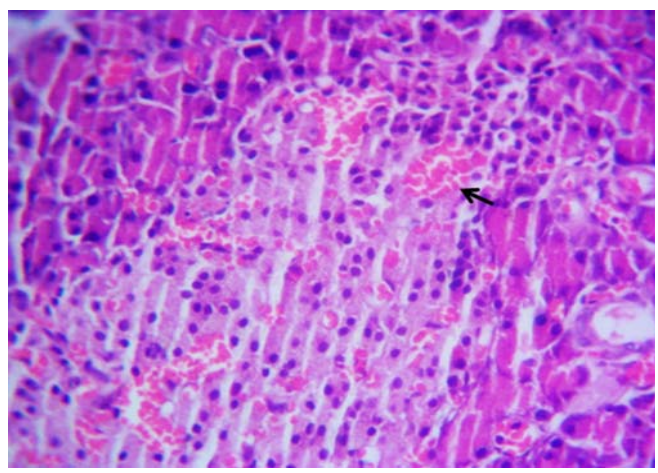

Photo. 7 (G7): Photomicrograph of rat's pancreas showing increase vascularization (arrow) between regenerated islets cells $\mathrm{H} \& \mathrm{E}$ (X400).

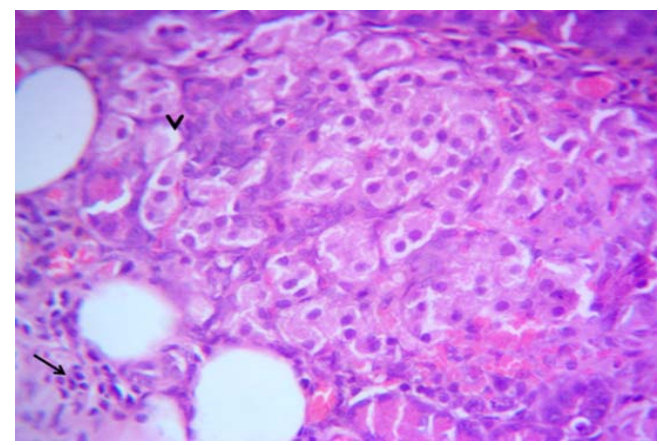

Photo. 4 (G4): Photomicrograph of rat's pancreas showing degenerative and earily necrotic changes (arrow head) in most of the $\beta$-cells and periductal lymphocytic infiltration (arrow) H\&E (X400).

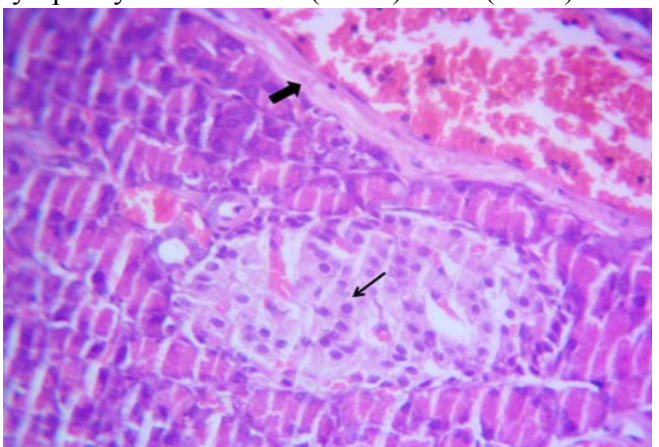

Photo. 6 (G6): Photomicrograph of rat's pancreas showing apparently normal pancreatic acini and islets of Langerhans (arrow) with congested pancreatic blood vessels (thick arrow) $\mathrm{H} \& \mathrm{E}(\mathrm{X} 400)$.

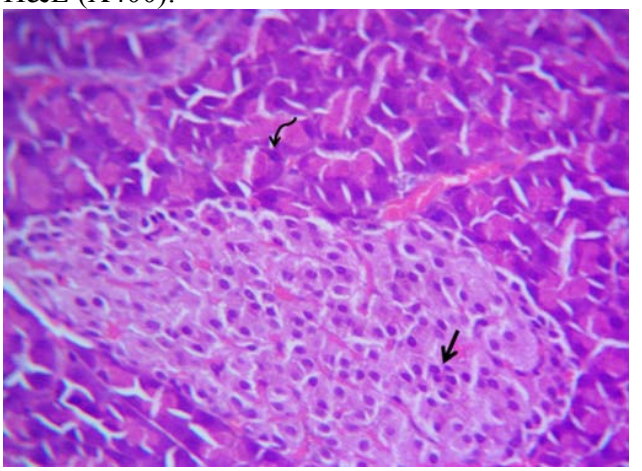

Photo. 8 (G8): Photomicrograph of rat's pancreas showing apparently normal pancreatic acini (curved arrow) and islets cells (arrow) H\&E (X400). 
Results demonstrated that the best result of histopathological examination was noticed in pancreatic tissue of diabetic rats fed on cakes enhanced with fresh pumpkin and $40 \%$ whole pumpkin seeds as comparing with diabetic rats (Table 11). This result is in accordance with findings of glucose and insulin values in current study. This result is also consistent with previous results for lipid profile as well as kidney and liver functions in the present study.

Table 11: The severity of the histopathological alteration in the pancreatic tissues of diabetic rats treated with different kinds of cakes.

\begin{tabular}{|l||c|c|c|c|c|c|c|c|}
\hline Parameters & G1 & G2 & G3 & G4 & G5 & G6 & G7 & G8 \\
\hline \hline Degenerative changes of Islets cells & - & +++ & +++ & + & + & + & - & - \\
\hline Islets cell deaths (apoptosis) & - & +++ & +++ & ++ & + & + & + & - \\
\hline Inflammatory cells infiltration & - & ++ & ++ & + & + & - & - & - \\
\hline Regenerative attempts & - & - & - & - & - & + & ++ & ++ \\
\hline
\end{tabular}

-: No alterations +: Mild (25-39\% alterations).

++: Moderate (40-65\% alterations). +++ : Severe (up to $65 \%$ alterations).

\section{Conclusion:}

The present study showed that cakes prepared with $10 \%$ fresh pumpkin fruit (as dry weight) and 40\% whole pumpkin seeds were the most acceptable compared with control cakes. These cakes have low values of fat and calories, while, have high levels of protein, fiber, phenolics and flavonoids as compared with control cakes. Therefore, cakes prepared from pumpkin or pumpkin and its seeds which were produced by the lowest cost could be beneficial for people suffering from diabetes as well as hyperlipidemia, obesity and malnutrition. 


\section{References:}

Abril, L.V., David, A. B., Luis, A. C. and Arturo, F. C. (2012). Protein fortification of corn tortillas: Effects on physicochemical characteristics, nutritional value and acceptance. Food and Nutr. Sci. 3: 1658-1663.

Abul-Fadl, M. M., Ibrahium, M. I., Abdel-Maksoud, B. S. and Ghanem, S. M. (2016). Effect of low calories pan bread containing wheat bran and some vegetable flours on biological properties of diabetic rats. Middle East J. Appl. Sci. 6(2): 315-328.

Ahmad, I., Anjum, F. M. and Butt, M. S. (2001). Quality characteristics of wheat varieties grown in Pakistan from 1933-1996. Pak. J. Food Sci. 11:14.

Akwaowe, E. U., Ndon, B. A. and Etuk, E. U. (2000). Minerals and antinutrients in fluted pumpkin (Telfairia occidetalis Hook f.). Food Chem. 70:235-240.

Alsuhaibani, A. M. A. and Al-Kuraieef, A. N. (2018). Effect of low-calorie pumpkin jams fortified with soybean on diabetic rats: Study of chemical and sensory properties. J. of Food Quality. 2018 (2):1-7.

Al-Tamim, E. A. A. (2014). Effect of cake fortified with pineapple consumption on hyperuricemic rats. Curr. Sci. Int. 3(2): 71-77.

AOAC, (2012). Official Methods of Analysis. Association of Official Analytical Chemistry (A.O.A.C) International, $19^{\text {th }}$ ed., Gaithersburg, Maryland, USA.

Azizah, A. H., Wee, K. C., Azizah, O. and Azizah, M. (2009). Effect of boiling and stir frying on total phenolics, carotenoids and radical scavenging activity of pumpkin (Cucurbita moschato). Int. Food Res. J. 16: 45-51.

Batista, J. E. R., Braga, L. P., Oliveira, R. C. D., Silva, E. P. and Damiani, C. (2018). Partial replacement of wheat flour by pumpkin seed flour in the production of cupcakes filled with carob. Food Sci. Technol. Campinas. 38(2): 250-254.

Betoret, E., Betoret, N., Vidal, D. and Fito, P. (2011). Functional foods development: trends and technologies. Trends Food Sci. Technol. 22:498508. 
Bharti, S. K., Kumar, A., Sharma, N. K., Prakash, O., Jaiswal, S. K., Krishnan, S., Gupta, A. K. and Kumar, A. (2013). Tocopherol from seeds of Cucurbita pepo against diabetes: Validation by in vivo experiments supported by computational docking. J. Formos. Med. Assoc. 112(11): 676-690.

Bhaskarachary, K., Ananthan, R. and Longvah, T. (2008). Carotene content of some common (cereals, pulses, vegetables, spices and condiments) and unconventional sources of plant origin. Food chem. 106: 85-89.

Bhat, M. A. and Bhat, A. (2013). Study on physico-chemical characteristics of pumpkin blended cake. J. Food Process Technol. 4(9): 262.

Brand-Willians, W., Cuvelier, M. E. and Berset, C. (1995). Use of a free radical method to evaluate antioxidant activity. Food Sci. and Technol. 28(1): 25-30.

Burstein, M., Scholnick, H. R. and Morfin, R. (1970). Rapid method for isolation of lipoprotein from human serum by precipitation with polyanions. J. Lipid Res. 11(6): 385- 395.

Cerniauskiene, J., Kulaitiene, J., Danilcenko, H., Jariene, E. and Jukneviciene, E. (2014). Pumpkin fruit flour as a source for food enrichment in dietary fiber. Not. Bot. Horti. Agrobo. 42(1):19-23.

Chaney, S. G. (2006). Principles of Nutrition I: Macronutrients. In: Devlin, T.M. (ed.), Textbook of Biochemistry, with Clinical Correlation, $6^{\text {th }}$ ed. John Wiley and sons, New York, pp: 1071-1090.

Chen, X., Lei, Q., Bujiang, W., Zhijun, Z., Han, L., Yeni, Z. and Jinfu, L. (2019). Synergistic hypoglycemic effects of pumpkin polysaccharides and puerarin on Type II diabetes mellitus mice. Molecules. 24, 955.

Clerk, D. and Herbert, E. (2000). Food Facts. $4^{\text {th }}$ ed., Nelson and Son Ltd., pp: 55.

Devi, N. M., Prasad, R. V. and Palmei, G. (2018). Physico-chemical characterisation of pumpkin seeds. Int. J. Chem. Studies. 6(5): 828-831.

Dissanayake, D. M. R. H., Deraniyagala, S. A., Hettiarachchi, C. M. and Thiripuranathar, G. (2018). The study of antioxidant and antibacterial properties of skin, seeds and leaves of the Sri Lankan variety of pumpkin. IOSR J. Pharm. 8(2): 43-48. 
Doumas, B. T., Waston, W. A. and Briggs, H. I. (1971). Albumin standers and measurements of serum albumin with Bromocresol. Clin. Chem. Acta.31:8.

Doumas, B. T. (1975). Standards for total serum protein assays--a collaborative study. Clin. Chem. 21(8):1159-66.

El-Adawy, T. A. and Taha, K. M. (2001). Characteristics and composition of watermelon, pumpkin, and paprika seed oils and flours. J. Agric. Food Chem. 49:1253-1259.

Elella, F. A. and Mourad, R. (2015). Anticancer and anti-oxidant potentials of ethanolic extracts of Phoenix dactylifera, Musa acuminata, and Cucurbita maxima. Res. J. Pharm. Biol. and Chem. Sci. 6:710-720.

Elkotby, D., Hassan, A. K., Emad, R. and Bahgat, I. (2018). Histological changes in islets of Langerhans of pancreas in alloxan-induced diabetic rats following Egyptian honey bee venom treatments. Int. J. Pure and Appl. Zool. 6(1): 1-6.

Ersedo, T. L. (2019). Chemical and Sensory Evaluations of Wheat (Triticum aestivum L.) Bread Enriched with Pumpkin (Cucurbita maxima L.) Flour. Int. J. Food Sci. and Nutr. Eng. 9(1): 24-30.

Famakin, O., Fatoyinbo, A., Ijarotimi, O. S., Badejo, A. A. and Fagbemi, T. N. (2016). Assessment of nutritional quality, glycaemic index, antidiabetic and sensory properties of plantain (Musa paradisiaca)-based functional dough meals. J. Food Sci. and Technol. 53(11): 3865-3875.

Farid, H. E. A., EL-Sayed, S. M. and Abozid, M. M. (2015). Pumpkin and sunflower seeds attenuate hyperglycemia and protect liver in alloxaninduced diabetic rats. Res. J. Pharm. Biol. and Chem. Sci. 6(5):1269-1279.

Fedha, M. S. (2008). Physicochemical characterization and food application potential of pumpkin (Cucurbita Sp.) fruit and seed kernel flours. M.Sc. Thesis. Dept. Food Sci. and Postharvest Technol. Jomo Kenyatta Univ. Agric. and Technol. Kenya.

Fossati, P. and L. Prencipe (1982). Serum triglycerides determined colorimetrically with an enzyme that produces hydrogen peroxide. Clin. Chem. 28(10): 2077-2080. 
Friedewald, W. T., Levy, K. T. and Fredrickson, D. S. (1972). Estimation of the concentration of low density lipoprotein cholesterol in plasma without use of the preparative ultracentrifuge. Clin. Chem. 226: 499-504.

Goetzke, B., Nitzko, S. and Spiller, A. (2014). Consumption of organic and functional food. A matter of well-being and health? Appetite 77:94-103.

Gutch, M., Razi, S. M., Kumar, S. and Gupta, K. K. (2014). Diabetes mellitus: trends in northern India. Indian. J. Endocrinol. Metab. 18:731734.

Hosseini Ghaboos, S. H., Seyedain Ardabili, S. M. and Kashaninejad, M. (2018). Physico-chemical, textural and sensory evaluation of sponge cake supplemented with pumpkin flour. Int. Food Res. J. 25(2): 854-860.

Hunt, L. M., Arar, N. H. and Akana, L. L. (2000). Herbs, prayer and insulin: Use of medical and alternative treatments by a group of Mexican American diabetes patients. J. Fam. Pract. 49: 216-223.

IBM SPSS Statistics. (2017). IBM SPSS Statistics for Windows, Version 25.0. IBM Corp., Armonk, New York.

IDF Diabetes Atlas. (2019). International Diabetes Federation. $9^{\text {th }}$ ed. Brussels. pp. 34-68.

Khalifa, A. H., Abdel-Rahman, E. A., Mohamed, S. A. and Al-Barbari, F. S. (2012). characteristics of seeds and seed oils of some Egyptian pumpkin cultivars. J. Food and Dairy Sci. Mansoura Univ. 3 (12): 681697.

Khalil, E. A. M. (2004). Biochemical and histopathological studies on the influence of aqueous extract of fenugreek seed (Trigonella foenum graecum) on alloxan diabetic male rats. Egypt. J. Hosp. Med.15:83 - 94.

Kindiki, M. M. (2017). Development of a nutritious composite flour from pearl millet (Pennisetum glaucum) and pumpkin fruit (Cucurbita pepovariety styriaca). M.Sc. Thesis. Dept. Food Sci. and Nutr. Jomo Kenyatta Univ. Agric. and Technol., Kenya.

Klein, B. and Kaufman, J. H. (1967). Automated alkaline phosphatase determination: III. Evaluation of Phenolphthalein Monophosphate. Clin. Chem. 13(4): 290-298. 
Kulczyński, B., Gramza Michałowska, A. and Królczyk, J. B. (2020). Optimization of extraction conditions for the antioxidant potential of different pumpkin varieties (Cucurbita maxima). Sustainability.12:1305.

Kushawaha, D. K., Yadav, M., Chatterji, S., Maurya, G. S., Rai, A. K. and Watal, G. (2016). Free radical scavenging index of Cucurbita maxima seeds and their LIBS based antioxidant elemental profile. Int. J. Pharm. and Pharm. Sci. 8: 344-350.

Kushawaha, D. K., Yadav, M., Chatterji, S. and Watal, G. (2018). Antihyperlipidemic potential of Cucurbita maxima seeds in streptozotocin induced diabetic rats. Int. J. Biol. Med. Res. 9(2):6309-6312.

Larson, K. (1972). Creatinine assay by a reaction-kinetic principle. Clin. Chim. Acta. 41: 209-217.

Lotfy, T. M. R., Mahfouz, M. Z. and Youssef, M. M. (2017). Effect of different cooking methods on natural antioxidants in pumpkin (Cucurbita moschata) products. Alex. J. Fd. Sci. and Technol. 14(2): 17-24.

Malkanthi, H. H. A. and Umadevi, S. H. (2018). Effect of dried pumpkin pulp and seed powder on physical, chemical and sensory properties of biscuits. Int. J. Scient. Res. 7 (8): 31-34.

Milovanoic, M. M. and Vucelic-Radovic, B. V. (2008). Sources, nutritional and health value of omega-3 and omega-6 fatty acids. J. Agric. Sci. 53: 203-13.

Muruganantham, N., Solomon, S. and Senthamilselvi, M. M. (2016). Antimicrobial activity of Cucurbita maxima flowers (Pumpkin). J. Pharmacogn. and Phytochem. 5(1):15-18.

Narayan, K. M., Gregg, E. W., Fagot-Campagna, A., Engelgau, M. M. and Vinicor, F. (2000). Diabetes--a common, growing, serious, costly, and potentially preventable public health problem. Diabetes Res. Clin. Pract. 50 (2): S77-S84.

Nyam, K. L., Lau, M. and Tan, C. P. (2013). Fibre from pumpkin (Cucurbita реро L.) seeds and rinds: physico-chemical properties, antioxidant capacity and application as bakery product ingredients. Malays. J. Nutr. 19(1):99-109. 
Oğuz, A. and Sayaslan, A. (2019). Antioxidant properties of roasted wholegrain, oilseed and nut snacks and effect of roasting process on these properties. Akademik Gida. 17(2): 149-156.

Patton, C. J. and Crouch, S. R. (1977). Spectrophotometric and kinetics investigation of the Berthelot reaction for the determination of ammonia. Anal. Chem. 49(3): 464-469.

Păucean, A. and Man, S. (2014). Physico-chemical and sensory evaluations of wheat bread with pumpkin (Cucurbita maxima) pulp incorporated. J. Agroaliment. Proc. and Technol. 20(1): 26-32.

Ramadan, B. K., Mohammad, S. A., Mahmoud, E. S. and Ouda, E. A. (2016). Role of pumpkin seeds oil on some cardiovascular and renal aspects in adult male albino rats. Al-Azhar Med. J. 45(4):931-955.

Ramesh, B. and Pugalendi, K. V. (2006). Antihyperglycemic effect of Umbelliferone in streptozotocin-diabetic rats. J. Med. Food. 9(4):562-566.

Reeves, R., Nielsen, G. F. H. and Fahey, G. C. (1993). AIN-93 purified diets for laboratory rodents. J. Nutr. 123:1939.

Reitman, S. and Frankel, S. (1957). A calorimetric method for determination of serum AST. Am. J. Clin. Path. 18:26.

Richmond, N. (1973). Preparation and properties of a cholesterol oxidase from Nacardia sp. enzymatic assay of total cholesterol in serum. Clin. Chem. 19 (12): 1350-1356.

Różyło, R., Gawlik-Dziki, U., Dziki, D., Jakubczyk, A., Karaś, M. and Różyło, K. (2014). Wheat Bread with Pumpkin (Cucurbita maxima L.) Pulp as a Functional Food Product. Food Technol. Biotechnol. 52 (4): 430-438.

Ryan, E., Galvin, K., O'Connor, T. P., Maguire, A. R. and O'Brien, N. M. (2007). Phytosterol, squalene, tocopherol content and fatty acid profile of selected seeds, grains and legumes. Plant Foods Hum. Nutr. 62: 85-91.

Sabudak, T. (2007). Fatty acid composition of seed and leaf oils of pumpkin, walnut, almond, maize, sunflower and melon. Chem. Natural Compounds. 43: 465-67. 
Saraswathi, D., Renu, R. and Maloo S. (2018). Development and quality evaluation of pumpkin seeds and flaxseeds powder incorporated biscuits. In. J. Food Sci. and Nutr. 3(2): 78-83.

See, E. F., Wan Nadiah, W. A. and Noor Aziah, A. A. (2007). Physicochemical and sensory evaluation of breads supplemented with pumpkin flour. ASEAN Food J. 14(2):123-30.

Sello, A. A. and Mostafa, M. Y. A. (2017). Enhancing antioxidant activities of cupcakes by using pumpkin powder during storage. J. Food and Dairy Sci. Mansoura Univ. 8 (2): 103-110.

ShanChen, Khan, B. M., Cheong, K. L. and Liu, Y. (2019). Pumpkin polysaccharides: Purification, characterization and hypoglycemic potential. Int. J. Biol. Macromol. 139: 842-849.

Sharma, A., Sharma, A. K., Chand, T., Khardiya, M. and Yadav, K. C. (2013). Antidiabetic and antihyperlipidemic activity of Cucurbita maxima duchense (pumpkin) seeds on streptozotocin induced diabetic rats. J. Pharmacogn. and Phytochem.1(6):108-116.

Singh, J., Singh, V., Shukla, S. and Rai, A. K. (2016). Phenolic content and antioxidant capacity of selected cucurbit fruits extracted with different solvents. J. Nutr. and Food Sci. 6(6): 565.

Singleton, V. L., Orthofer, R. and Lamuela-Raventos, R. M. (1999). Analysis of total phenols and other oxidation substrates and antioxidants by means of Folin Ciocalteu reagent. Methods Enzymol. 299:152-178.

Sojak, M. and Glowacki, S. (2010). Analysis of giant pumpkin (Cucurbita maxima) drying kinetics in various technologies of convective drying. J. Food Eng. 99: 323-329.

Song, H. and Sun, Z. (2017). Hypolipidaemic and hypoglycaemic properties of pumpkin polysaccharides. 3 Biotech. 7(3): 159.

Stevenson, D. G., Eller, F. J., Wang, L., Jane, J. L., Wang, T. and Inglett, G. E. (2007). Oil and tocopherol content and composition of pumpkin seed oil in 12 cultivars. Agric. Food Chem. 55(10): 4005-4013.

Suvarna, K. S., Christopher, L. and Bancroft, J. D. (2013). Bancroft's theory and practice of histological techniques, $7^{\text {th }}$ Edition. 
Temple, R. C., Clark, P. M. and Hales, C. N. (1992). Measurement of insulin secretion in type 2 diabetes: problems and pitfalls. Diabet. Med. 9 (6): 503-512.

Trinder, P. (1969). Determination of glucose in blood using glucose oxidase with an alternative oxygen acceptor. Ann. Clin. Biochem. 6 (1): 24-27.

Tripathi, B. K. and Srivastava, A. K. (2006). Diabetes mellitus: complications and therapeutics. Med. Sci. Monit. 12(7):RA130-RA147.

Zdrojewicz, Z., Braszczok, A. and Wróblewska, M. (2016). Pumpkin healthy, but forgotten. Med. Rodz. 19(2):70-74.

Zhao, J., Liu, W., Dong, C., Yi, S., Yuyu, Z., Yuanying, N. and Quanhong, L. (2015). Physico-chemical and antioxidant properties of different pumpkin cultivars grown in China. Adv. J. Food Sci. and Technol. 9(4): 308-316.

Zheng, H., Whitman, S. A., Wu, W., Wondrak, G. T., Wong, P. K., Fang, D. and Zhang, D. D. (2011). Therapeutic potential of Nrf2 activators in streptozotocin-induced diabetic nephropathy. Diabetes. 60: 3055-3066.

Zhishen, J., Mengcheng, T. and Jianming, W. (1999). The determination of flavonoid contents in mulberry and their scavenging effects on superoxide radicals. Food Chem. 64(4): 555-559. 


\section{الملخص العربي}

\section{التقييم التغذوي والحسي والتأثير البيولوجي علي الفئران المصابه بمرض السكري للكيك المُحسن بفاكهة اليقطين ويذورها}

الغرض من الدراسة الحالية هو زيادة القيمة الغذائية للكيك عن طريق استبدال دقيق القمح بفاكهة اليقطين وبذورها كمصدر للبروتين والمركبات الفينولية والفلافونويدات. وقد تم تحضير الكيك باستبدال

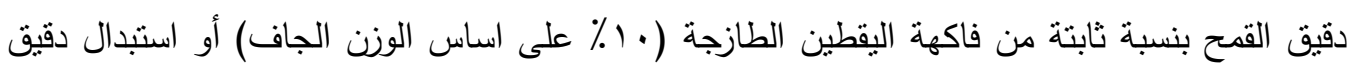

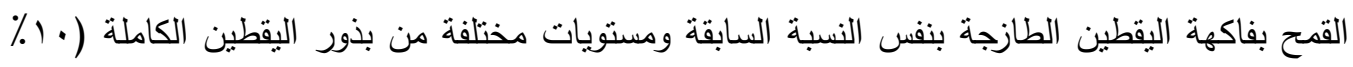

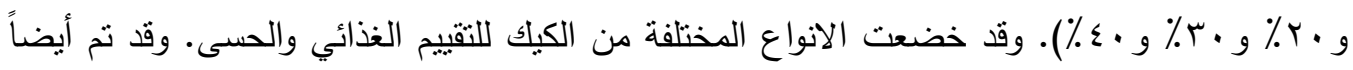

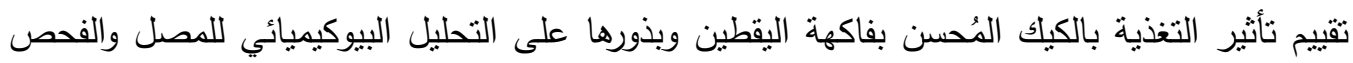
النسيجي للبنكرياس لذكور الفئران المصابة بمرض البول السكري الذى يُسبيه الالوكزان بعد ثلاثة أنثهر

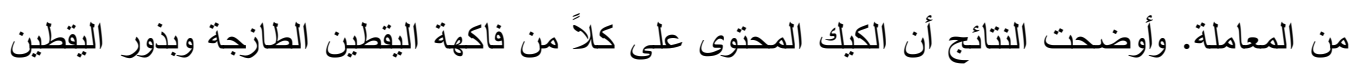
الكاملة أظهر زيادة معنوية (P<0.05) في محتوى البروتين والألياف والرماد والمركبات الفينولية والفلافونويدات وارتبطت هذه الزيادة بمستوى الاستبدال ببذور اليقطين الكاملة مقارنة بالكيك الكنترول.

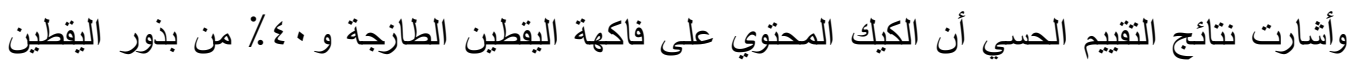

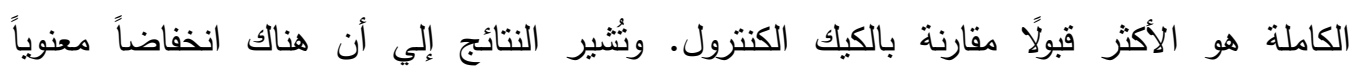
في مستويات الجلوكوز والدهون الثلاثية والكوليسترول والليبوبروتينات منخفضة الكثافئة

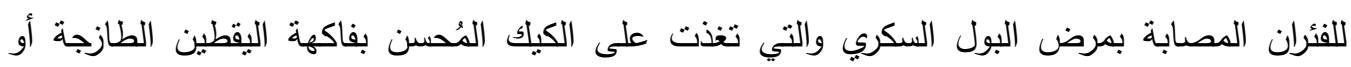
الكيك الذى يحتوي على كلاً من فاكهة اليقطين الطازجة ومستويات مختلفة من بذور اليقطين الكاملة

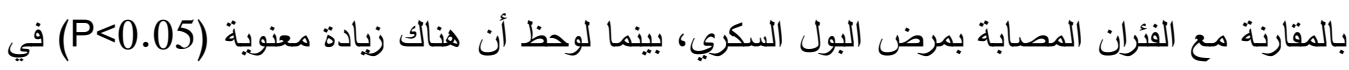

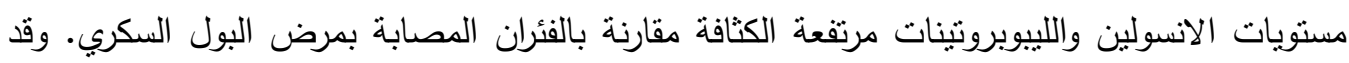

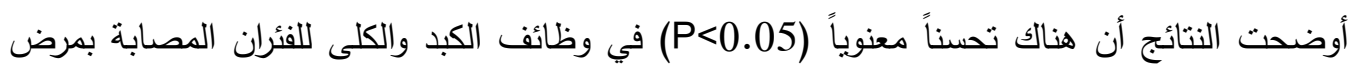
البول السكري والمعاملة بالكيلك المُحسن باليقطين (الفاكهة أو الفاكهة وبذورها) مقارنة بالفئران المصابة

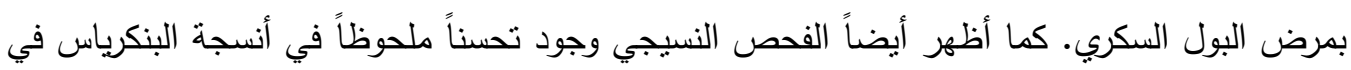
الفئران المصابة بمرض البول السكري المعاملة بالكيك المُحسن باليقطين وبذورة مقارنة مع الفئران

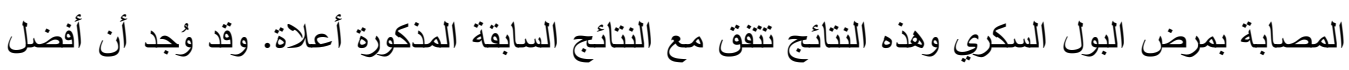

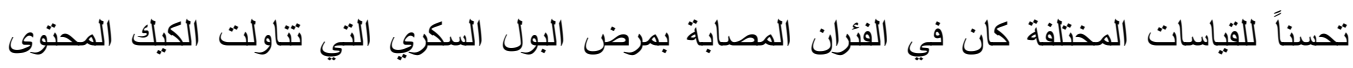

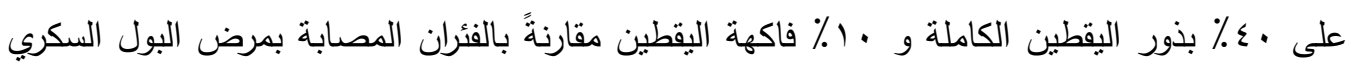


حيث وصلت القياسات إلي القيم الطبيعية تقريباً. وبالاضافة إلي ذلك، بحتوى هذا الكيك على أعلى قيم

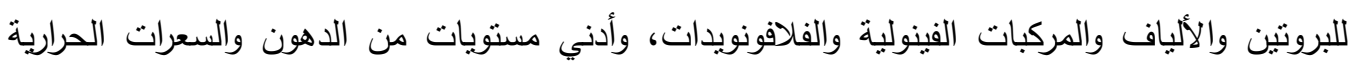
مقارنة بالكيك الكنترول. من ذلك نستتتج أن الكيك المحضر من اليقطين (الفاكهة أو الفاكهة وبذورها)

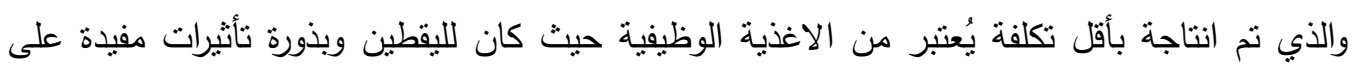

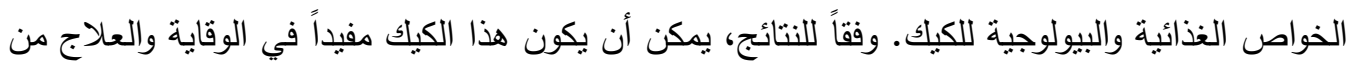

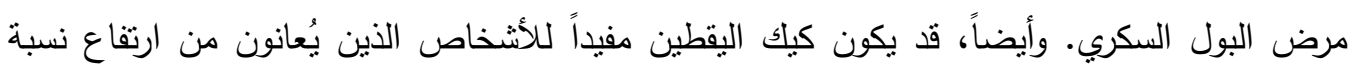
الدهون في الدم والسمنة وسوء التغذية، وبالتالى سوف يساعد ذلك على نتجيع استخدام كيلك اليقطين ومعالجة المشاكل المتعلقة بالتغذية في مصر . لذلك توصي هذه الدراسة بزيادة إنتاج المنتجات الغذائية التي تحتوى على اليقطين (الفاكهة أو الفاكهة وبذورها) وتحسين الثقافة الغذائية للناس حول أهمية تناول

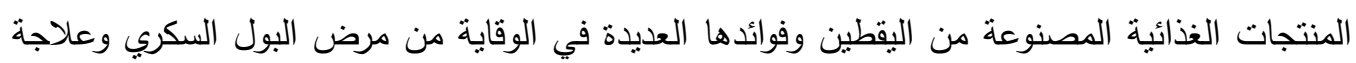
وكذلك الأمراض الآخرى عبر وسائل الإعلام المختلفة.

الكلمات المفتاحية: اليقطين - بذور اليقطين الكاملة - مرض البول السكري - الكيك - الالوكزان القيمة الغذائية - التقييم الحسى. 